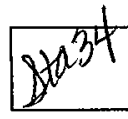

2. To: (Receiving Organization)

Distribution

5. Proj./Prog./Dept./Div.:

W-504/TWRS Priv. Phase I/

Infrastructure

8. Originator Remarks:

Issued for release.

11. Receiver Remarks:

11A. Design Basel ine Document?

$[X]$ Yes
3. From: (Originating Organization)

D. L. Fort/Numatec

6. Design Authority/ Design Agent/Cog. Engr.:

JMetoche/KDBare/DL Fort

4. Related EDT NO.:

619944,612809

7. Purchase Order No.:

N/A

9. Equip./Component No.:

$N / A$

10. System/Bldg./Facility:

$N / A$

12. Major Assm. Dwg. No.: N/A

13. Permit/Permit Application No.: $\mathrm{N} / \mathrm{A}$

14. Required Response Date: $N / A$

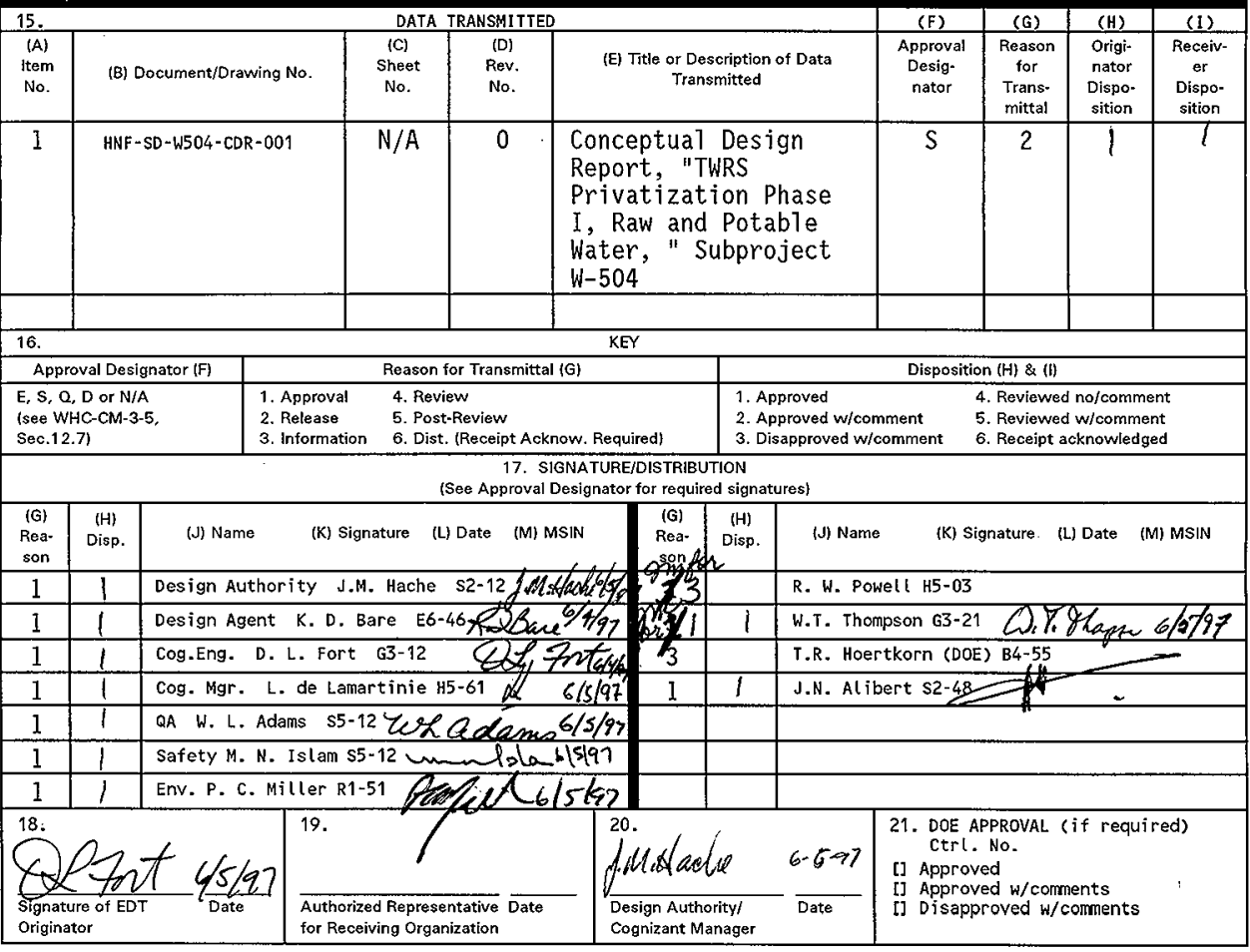




\title{
Conceptual Design Report, "TWRS Privatization Phase I, Raw and Potable Water, " Subproject W-504.
}

Gurdhian Singh

Numatech Hanford Corporation, Richland, WA 99352

U.S. Department of Energy Contract DE-AC06-96RL13200

\author{
EDT/ECN: $615904 \quad$ UC: 510 \\ Org Code: 8C470 Charge Code: D6327 \\ B\&R Code: EW3130010 Total Pages: 95
}

Key Words: CDR, Conceptual Design Report, Raw, Potable, PC, Privatization, TWRS, Private Contractor, $W-504$.

Abstract: This document includes Conceptual Design Report (CDR) for extension of existing Raw and Potable systems from 200-East Area systems to two new private contractor facilities for immobilization and disposal of low-activity waste (LAW). The work will include design and installation of almost $3400 \mathrm{~m}(11,200 \mathrm{ft})$ of raw water pipe and $2200 \mathrm{~m}$ $(7,300 \mathrm{ft})$ of potable water pipe.

TRADEMARK DISCLAIMER. Reference herein to any specific commercial product, process, or service by trade name, trademark, manufacturer, or otherwise, does not necessarily constitute or imply its endorsement, recommendation, or favoring by the United States Government or any agency thereof or $i$ ts contractors or subcontractors.

Printed in the United States of America. To obtain copies of this document, contact: Document Control Services, P.0. Box 950, Mailstop H6-08, Richland WA 99352, Phone (509) 372-2420; Fax (509) 376-4989.
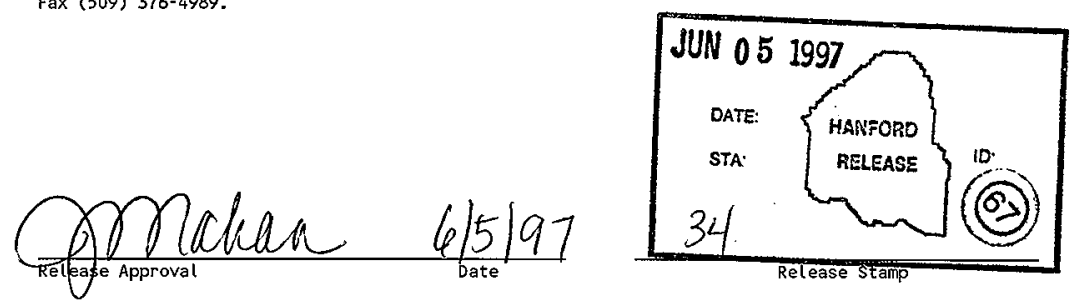


\section{Conceptual Design Report TWRS Privatization Phase I Raw and Potable Water Subproject W-504}

Prepared for the U.S. Department of Energy Assistant Secretary for Environmental Management 
CONCEPTUAL DESIGN REPORT

TWRS PRIVATIZATION PHASE I

\title{
RAW AND POTABLE WATER \\ SUBPROJECT W-504
}

\author{
Prepared for \\ Numatec Hanford Corporation \\ June 1997 \\ Prepared by \\ Fluor Daniel Northwest \\ Richland, Washington
}

W504CDR 


\title{
W504CDR
}

CONCEPTUAL DESIGN REPORT

FOR

\section{TWRS PRIVATIZATION PHASE I}

RAW AND POTABLE WATER

\author{
SUBPROJECT W-504
}

\section{APPROVED}

Fluor Daniel Northwest
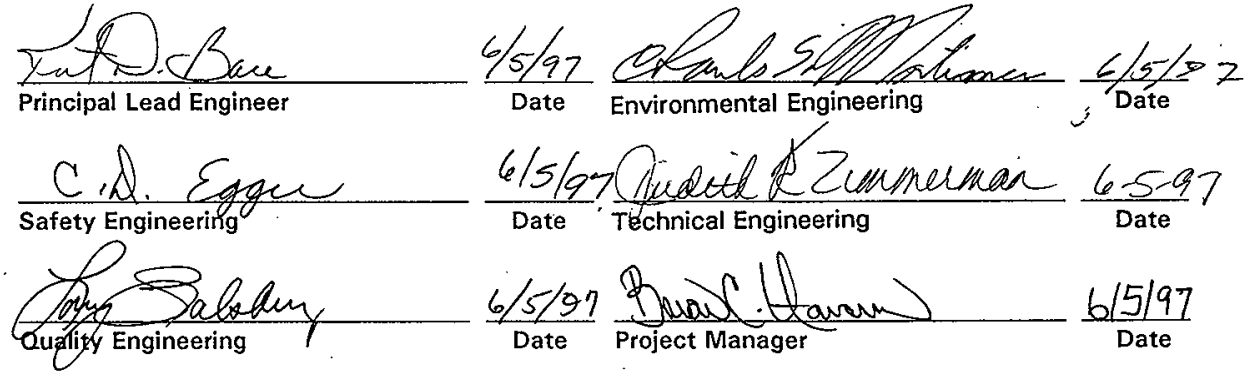

Numatec Hanford Corporation

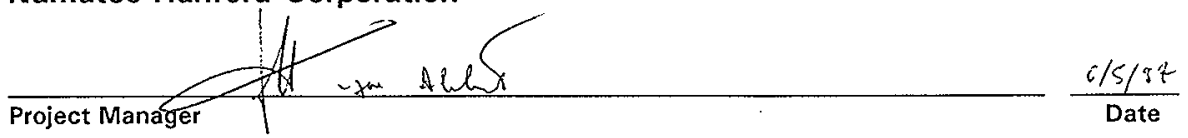




\section{TABLE OF CONTENTS}

I. INTRODUCTION $\ldots \ldots \ldots \ldots \ldots \ldots \ldots \ldots \ldots \ldots \ldots \ldots \ldots \ldots$

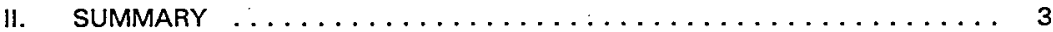

11I. JUSTIFICATION $\ldots \ldots \ldots \ldots \ldots \ldots \ldots \ldots \ldots \ldots \ldots \ldots \ldots$

IV. DESCRIPTION OF PROJECT SCOPE $\ldots \ldots \ldots \ldots \ldots \ldots \ldots \ldots \ldots$

A. IMPROVEMENTS TO LAND (460) ............ 4

B. OTHER PROJECT COSTS $(900) \ldots \ldots \ldots \ldots \ldots \ldots \ldots \ldots$

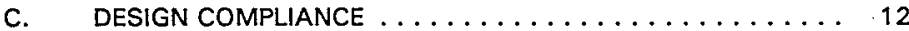

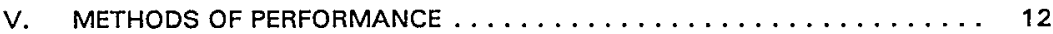

A. ENGINEERING (WBS 1.0$) \ldots \ldots \ldots \ldots \ldots \ldots \ldots \ldots$

B. PROCUREMENT (WBS 2.0$) \ldots \ldots \ldots \ldots \ldots \ldots \ldots \ldots$

C. CONSTRUCTION (WBS 3.0 ) ............... 13

D. PROJECT MANAGEMENT (WBS 4.0 ) $\ldots \ldots \ldots \ldots \ldots \ldots$

E. OTHER PROJECT COSTS (WBS 5.0$) \ldots \ldots \ldots \ldots \ldots \ldots, 14$

VI. REQUIREMENTS AND ASSESSMENTS $\ldots \ldots \ldots \ldots \ldots \ldots \ldots \ldots \ldots$

A. SAFEGUARDS AND SECURITY $\ldots \ldots \ldots \ldots \ldots \ldots \ldots, 15$

B. HEALTH AND SAFETY ................ 15

C. DECONTAMINATION AND DECOMMISSIONING $\ldots \ldots \ldots, 16$

D. PROVISIONS FOR FALLOUT SHELTERS ........... 16

E. MAINTENANCE AND OPERATION REQUIREMENTS . . . . . 17

F. AUTOMATED DATA PROCESSING EQUIPMENT ....... 17

G. QUALITY ASSURANCE/SAFETY CLASSIFICATION $\ldots \ldots \ldots 17$

H. ENVIRONMENTAL COMPLIANCE $\ldots \ldots \ldots \ldots \ldots \ldots \ldots 18$

I. PERMITS ..................... 19

J. UNREVIEWED SAFETY QUESTION $\ldots \ldots \ldots \ldots \ldots \ldots .19$

K. POLLUTION PREVENTION/WASTE MINIMIZATION $\ldots \ldots \ldots 19$

VII. IDENTIFICATION AND ANALYSIS OF UNCERTAINTIES $\ldots \ldots \ldots \ldots \ldots 20$

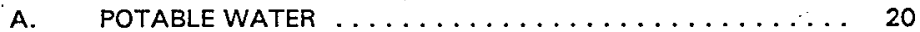

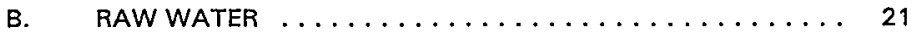

C. CONTROL OF CONTAMINATED SOILS $\ldots \ldots \ldots \ldots \ldots 24$

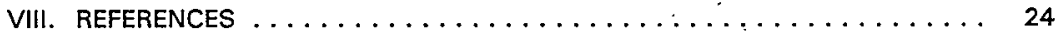

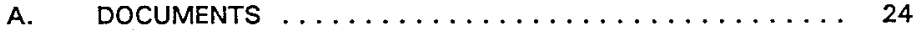

B. CODES AND STANDARDS $\ldots \ldots \ldots \ldots \ldots \ldots \ldots \ldots, 26$

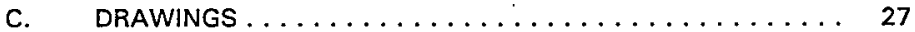




\section{APPENDICES}

Appendix A. Work Breakdown Structure

Appendix B. Budget Authorized/Budget Outlay Schedule

Appendix C. Cost Estimate Summary

Appendix D. Conceptual Project Schedule

Appendix E. Outline Specification

Appendix F. Energy Conservation Report and Analysis

Appendix G. Unreviewed Safety Question Evaluation

Appendix $\mathrm{H}$. Economic Analysis and Life Cycle Cost Analysis

Appendix I. Physically Handicapped Assessment

Appendix J. Plant Forces Work Review

Appendix K. Pollution Prevention/Waste Minimization Plan

Appendix L. Sketches 


\section{ABBREVIATIONS}

CDR

CW

DOE

DRD

FDAS

HAW

HDPE

HPT

LAW

NFPA

NOC

P2/WMin

$\mathrm{PC}$

PHMC

PIV

PVC

PW

QAPP

RFP

RL

RLID

RW

TEDF

TWRS

WAC

WBS

WDOH

WDOT conceptual design report

cooling water

U.S. Department of Energy

design requirements document

field data acquisition system

high-activity waste

high-density polyethylene

health physics technician

low-activity waste

National Fire Protection Agency

notice of construction

pollution prevention/waste minimization

Privatization Contractors

Project Hanford Management Contractor post indicator valve

polyvinyl chloride

potable water

Quality Assurance Programi Plan

request for proposal

Richland Operations Office (DOE)

$\mathrm{RL}$ Implementing Directive

raw water

Treated Effluent Disposal Facility

Tank Waste Remediation System

Washington Administrative Code

work breakdown structure

Washington State Department of Health

Washington State Department of Transportation 


\title{
CONCEPTUAL DESIGN REPORT \\ TWRS PRIVATIZATION PHASE I
}

\author{
RAW AND POTABLE WATER
}

SUBPROJECT W-504

\section{INTRODUCTION}

Historically, the primary function of the 200 Areas facilities at the Hanford Site was to process nuclear material for defense purposes. This activity resulted in liquid radiological wastes that were stored in tank farms located in both the 200-East and 200-West Areas. High-activity waste (HAW) has been stored in large underground storage tanks at the Hanford Site since 1944; approximately $208 \mathrm{ML}(55 \mathrm{Mgal})$ of waste are stored in 177 tanks. These caustic wastes consist of many different chemicals in the form of liquids, slurries, saltcakes, and sludges. In 1992, the Tank Waste Remediation System (TWRS) program was established to manage, retrieve, treat, immobilize, and dispose of these wastes in a safe, environmentally-sound, and cost-effective manner.

The U.S. Department of Energy (DOE), Richland Operations Office (RL) is pursuing a new business strategy of hiring private contractors to manage the retrieval, immobilization, and disposal of low-activity wastes (LAWs). Privatization strategy includes design, permitting, construction, operation and deactivation of equipment and facilities for treatment of tank wastes. The approach to privatization will be conducted in two phases. Phase I will be a proof-of-concept/commercial demonstration phase and includes supernatant pretreatment, LAW immobilization, and an optional HAW immobilization by two competing vendors.

Once proven on this relatively small scale, privatization will be expanded to Phase 11 , the full-scale production phase, through a second competition to 
dispose of the remainder of the tank waste. Phase II will be the full-scale production phase. Facilities will be sized so that all the remaining wastes can be processed and immobilized on a schedule that will accommodate removing the waste from the single-shell tanks by year 2018 and the double-shell tanks by 2028.

The TWRS Privatization Infrastructure Project is a part of the first phase of the privatization initiative and will develop a site to support the treatment of Hanford Site wastes. The project consists of four subprojects that will provide key physical interfaces and services needed to support the Privatization mission.

Subproject W-504 is one of the four projects that make up the TWRS Privatization Infrastructure Project. The subprojects provide the infrastructure (except for sanitary sewer), the site improvements, and interfaces necessary to support the demonstration phase (Phase l) of TWRS Privatization. The subprojects are:

- W-503, "Electrical Power System"

- W-504, "Raw and Potable Water"

- W-505, "Site Development and Roads"

- W-506, "Liquid Effluent Transfer Systems"

Subproject $W-504$ will provide the raw and potable water lines to supply the water requirements to the $\mathrm{PC}$ sites (ref 1 and 2 ).

In conjunction with preparation of the TWRS Privatization request for proposal (RFP) for the solicitation of Privatization Contractors (PC), a location was selected for the Phase I facilities (ref 3 ). The selected area is east of the major 200-East Area road and rail network, and requires modifications and additions to existing transportation corridors. The area was previously developed and characterized for the grouted waste vault disposal site. 
HNF-SD-W504-CDR-001, Rev. 0

This conceptual design report (CDR) documents raw (untreated process) water (RW) and potable water (PW) line routing and tie-in point locations.

The cost estimate summary and conceptual project schedule are in Appendices C and $D$, respectively.

\section{SUMMARY}

Subproject W-504 is one of four projects that will develop the infrastructure serving the needs for the Tank Waste Remediation System (TWRS) Privatization Phase I facilities. Under this subproject, new raw and potable water supply lines will be extended from the 200-East Area systems. The existing water systems have the reserve capacity to provide the quantities of water required by the two Privatization Contractors (PCs). The raw water will serve the fire suppression and untreated process water requirements for the PCs. The two pipelines will be placed in the same trench when routed to the PC sites and separated horizontally and vertically to facilitate future tie-in connections and maintenance.

The work will include the installation of almost $3400 \mathrm{~m}(11,200 \mathrm{ft})$ of raw water pipe and $2200 \mathrm{~m}(7,300 \mathrm{ft})$ of potable water pipe. Raw water piping is predominately DN300 (12-in.) pipe with a minor amount of DN200 (8 in.). The PW pipe consists of about $1475 \mathrm{~m}(4,900 \mathrm{ft})$ of DN100 (4 in.), and $725 \mathrm{~m}$ $(2,400 \mathrm{ft})$ of DN150 (6-in.) pipe. Sectional valves and fire hydrants will be installed on a limited basis in support of PC activities.

Subproject $W-504$ is a fiscal year 1999 General Plant Project. Total estimated costs (TEC) of the project are $\$ 1,640,000$; other project costs (expense funded) are $\$ 970,000$. The total subproject cost (TPC) is $\$ 2,610,000$. 


\section{JUSTIFICATION}

Raw and potable water are essential elements of the 200-East Area infrastructure. Expanding existing 200-East Area water systems is the most cost effective and timely way to satisfy the project milestones.

The upgrades provided by subproject W-504 are required to support the TWRS Privatization contracts (ref 4 and 5). By supporting TWRS Privatization, subproject W-504 supports the Tri-Party Agreement milestones for site clean-up, processing, and disposal of tank wastes.

\section{DESCRIPTION OF PROJECT SCOPE}

Subproject W-504 will provide water to the PC site during TWRS Privatization Phase I. Three types of water are required: PW, RW, and fire suppression water (RW describes both raw and fire suppression water). Subproject W-504 will provide reliable RW and PW service from the 200-East Area infrastructure by installing over $3400 \mathrm{~m}(11,200 \mathrm{ft})$ of new RW piping and $2200 \mathrm{~m}(7,300 \mathrm{ft})$ of PW supply piping. Upgrades to the PW and RW systems will be made to ensure reliable service. The improvements for the site will provide each PC with near equitable site conditions as reasonably possible.

\section{A. IMPROVEMENTS TO LAND (460)}

In this report, the references made to potable or sanitary water are synonymous. Existing record drawings and past practices on the Site used the term, "sanitary water," however, the current preferred terminology is, "potable water" (PW).

The Integrated Site Plan shows the land allocated to the PCs (see sketch ES-W504-C01. All sketches are shown in Appendix L). Equitable parcels of land are furnished with PW and RW, liquid effluent transfer piping, electrical power services, and paved access. The PC sites are highlighted on sketch ES-W504-C01. The RW and PW lines will be placed 
in the same trench with the PW line elevated on a bench to facilitate accessibility to both lines for future maintenance and service connection additions. The effluent transfer lines to the PC sites will be located on the opposite side of the road from the water lines. When the transfer lines heading south to the PC sites cross with the water lines, the single-wall effluent lines will be encased to protect the water lines.

Four fire hydrants will be installed by this infrastructure expansion (see sketch ES-W504-C02). A hydrant will be located near each PC site and the other two will be specifically located to satisfy the fire protection requirements for the subproject $W-503230 \mathrm{kV}$ substation.

The boundaries for each parcel have been established by using existing record drawings and aerial mapping information. The coordinates for each corner of each parcel are shown. Following initial survey work to establish property corners and to install site monumentation, work on the road subgrade and installation of the utilities will occur. Temporary use areas are also shown for each PC on sketch ES-W504-C01, identifying the land allocated for their use during construction, i.e. for parking, laydown areas, etc.

\section{Raw Water}

Raw water will be provided to the site via a DN300 (12-in.) supply line to serve the raw and fire suppression needs of the PC. The RW line will be a looped extension of the existing 200-East Area RW system with connections at the two locations (see sketch ES-W504-C02).

One tie-in point is located $30 \mathrm{~m}(100 \mathrm{ft})$ southeast of the 242-A Evaporator on the existing 12-in. $(300 \mathrm{~mm})$ polyvinyl chloride (PVC) RW line. From this point, the line will proceed south along Canton Avenue for approximately $600 \mathrm{~m}(2,000 \mathrm{ft})$. The northern portion of this segment, approximately $335 \mathrm{~m}(1,100 \mathrm{ft})$, will be placed inside an abandoned 16-in. 
steel cooling water (CW) line. The RW line will proceed east along the north side of the PC Loop Road and south of the 216-A-30 and 37-2 disposal crib areas to the southeast corner of the PCs parcels. The pipeline continues north along the east boundaries of the parcels, then, west along the north side of the northern parcel and returns to a second tie-in point $30 \mathrm{~m}$ north of the 207-A Basins on an existing 12-in. PVC RW main (see sketch ES-W504-CO2, Detail 3).

The primary reason for using the abandoned 16-in. CW line is to reduce the amount of excavation through the congested areas along Canton Avenue, near and around the 241-AW Tank Farm and the 272-AW Building. Locating a clear route for a new pipeline in this area is very difficult. If a new pipeline is installed using conventional methods, much of the route would have to be excavated by hand. The traffic disruption would become a major inconvenience to Plant operations. The direction in Letter of Instruction No. 2, complying with the design requirements document (DRD) and WHC-SD-TWR-ES-002, confirms that this is the preferred route (ref 1, 6, and 7, respectively). The installation cost for hand excavating and placing pipe 1.2 to $1.8 \mathrm{~m}$ (4) to $6 \mathrm{ft}$ ) deep are over two times the estimated cost to pull a DN300 high-density polyethylene (HDPE) pipe inside the abandoned 16-in. CW line. In addition, any interferences in the hand-excavated route would escalate the cost.

At initiation of definitive design, the condition of the existing 16-in. CW line will be evaluated by inserting a video camera into the line. The camera will inspect the full length of the pipe being considered for use. Two points of access (minimum) into the pipeline will be made to facilitate the video inspection. Following is the design and subsequent installation sequence. 
- The first tie-in connection will install a metal caisson to facilitate accessing the existing 12-in. RW main and to obtain entry into the existing 16-in. carbon steel $\mathrm{CW}$ pipeline. A $2700 \mathrm{~mm}(9-\mathrm{ft})$ inside diameter caisson will be used to install the pulleys and anchor assembly for pulling the DN300 HDPE line and to serve as a permanent manhole (see sketch ES-W504-C04). The caisson also serves as a shoring system as excavation extends approximately $4 \mathrm{~m}(13 \mathrm{ft})$ deep to access the CW pipeline. A precast HS-20-rated lid with hatch cover will be installed at finished grade to cap the caisson.

- The opposite end of the existing $\mathrm{CW}$ pipeline is about $1.5 \mathrm{~m}(5 \mathrm{ft})$ deep and can be excavated to expose the pipe. A $12 \mathrm{~m}(40 \mathrm{ft})$ length of the $\mathrm{CW}$ line will be removed to facilitate inserting the HDPE line inside the CW pipeline (see sketch ES-504-CO3).

- After obtaining access to both ends of the CW line, a steel mandrel will be passed back and forth through the pipeline to verify a clear passage and to remove any obstructions that may damage the HDPE pipe.

- The HDPE pipe will be installed from the south end, the HDPE sections fused together, and the pipe pulled into the CW line until it reaches the caisson. An adapter fitting, converting the HDPE to mate-up with cast iron flanged fittings, will be fused on inside the caisson.

- After the HDPE line is installed, flushed, and hydrostatically tested, the ends of the $16-\mathrm{in}$. CW will be sealed with 150 to $300 \mathrm{~mm} / 6$ to 12 in.) of grout and connected to the existing RW supply line. 
The northern tie-in connection can be made using standard ductile or cast-iron fittings and a gate valve (see sketch ES-W504-C05, Detail 3). The gate valve will serve as a sectional valve and will be equipped with a nonsupervised post indicator valve (PIV) extension, complete with post barricade. This will be typical for all sectional valves installed on the RW line unless the valve is located beneath the asphaltic concrete pavement, in which case, a valve box with a cast-iron lid will be installed.

On the north PC Loop Road, as the RW line crosses over the 216-A-29 ditch (Snows Canyon) embankment (constructed by subproject W-505), a DN600 nestable culvert pipe will be installed, extending a minimum of $15 \mathrm{~m}(50 \mathrm{ft})$ beyond the edge of the ditch embankment on each side. A $1.2 \mathrm{~m}$ (4-ft) diameter manhole will be installed at each end of the encasement to provide a monitoring point for leak detection. The manholes will double as a percolation sump and will be lined with a geotextile fabric and some gravel to allow dissipation of small amounts of water. The manholes will also provide a location for the installation of a tee and a sectional valve in the west manhole, allowing for the shutdown of the water line across the canyon in case of a pipeline break or a major leak.

Sectional valves have been spaced along the RW supply pipeline at specific locations, but not exceeding $366 \mathrm{~m}(1,200 \mathrm{ft})$ intervals to provide adequate isolation and shutoff capability for maintenance functions. Fire hydrants are located sparingly around PC Loop Road because there are no facilities or structures being threatened. The improvements proposed by the individual PCs will include fire protection amenities, including additional DN300 looped distribution pipe, fire hydrants, sectional valves, etc., within each site.

A DN200 (8-in.) RW tie-line will be installed to connect the existing 8-and 12-in. RW lines southeast of the 241-AX Tank Farm (see 
sketch ES-W504-C02). This will enhance the performance and improve the reliability in the RW distribution system.

\section{Potable Water}

The PW will be supplied by a DN100 mm (4-in.) PVC pipeline connected into the existing 200-East Area PW system. An existing 4-in. PVC PW line is adjacent to the RW line, north of the 207-A Basins. The PW line will extend east to the PC site by utilizing a same trench, paralleling the northern and eastern portions of the RW loop (see sketch ES-W504-C02). The tie-in connection will be made using standard ductile or cast-iron fittings and gate valves as shown on sketch ES-W504-C05, Detail 3.

Similar to the RW line, the PW line will be encased in a DN300, nestable pipe culvert with the same $15 \mathrm{~m}$ extension beyond the ditch embankment. At each end of the pipeline encasement, a manhole will be installed as an inspection port to allow detection of leakage. A nonsupervised PIV and a tee with a blind flange will be installed to allow for isolating the line and for any future pipeline rerouting.

Two specific design measures are being taken to ensure flow and pressure reliability to PC sites (see sketch ES-W504-C02). The first requires the installation of a new northern tie-line that will provide a second $\mathrm{PW}$ source to the east side of the 200-East Area grid (see sketch ES-W504-CO6). The second measure involves replacing a small portion of deteriorated 6-in. carbon steel PW pipe that remains in service near the 275-EA Building (see sketch ES-W504-C07).

The installation of a northern tie-line will significantly improve the flow and pressure characteristics of the PW system. Approximately $725 \mathrm{~m}$ $(2,400 \mathrm{ft})$ of new DN150 (6-in.) pipe will be installed (see sketch ES-W504-C06). A tie-in point will be made on the existing 12-in. PW line located southwest of the 241-C Tank Farm, off 7th Street. The 
line will continue parallel to the diagonal road heading northeast, then east along 8th Street, and across Canton Avenue where it will intersect with the existing 4-in. PW pipeline.

The route is clear of any known underground obstructions and the risk of encountering contaminated soils is low. The existing PW system has a dead-end leg serving the Treated Effluent Disposal Facility (TEDF). Installation of this tie-in line will provide a redundant source to the facilities on the east side of 200-East Area. It will also facilitate isolation capability when performing routine maintenance and when replacing the deteriorated portion of the 6-in. PW line.

Replacing the deteriorated 6-in. carbon steel PW pipe, south of the 275-EA facility, will also enhance the PW grid piping. During the winter of 1996/97, severe leaking occurred in a $75 \mathrm{~m}(250-\mathrm{ft})$ stretch of deteriorated 6-in. carbon steel PW pipe, and all but approximately $18 \mathrm{~m}$ $(60 \mathrm{ft})$ of the pipe was removed and replaced. The small remaining length is of questionable integrity but it was left in-place because of difficulties in isolating the flow to essential facilities. Upon completion of the northern tie-line, flow can be isolated at this location without interruption to essential facilities. The work involves isolating the line, relocating the existing fire hydrant, capping-off the abandoned piping, and installing about $18 \mathrm{~m}$ of new DN150 PW line. Reconnecting the hydrant, flushing, testing, and disinfecting the line will complete the installation (see sketch ES-W504-CO7).

Concurrent with subgrade construction on subproject W-505, subproject W-504 will install the RW and PW pipelines. A single trench will be excavated for both lines. A separation distance of $1200 \mathrm{~mm}(4 \mathrm{ft})$ will be required, allowing for accessibility for future maintenance and operation. 
By coordinating construction efforts to ensure that the four subprojects are completely integrated, many activities can be performed concurrently to minimize the schedule. For example, while much of the roadwork described in subproject W-505 is underway, some of the water lines can be installed with minimal interference. The installation of the DN150 northern tie-line, the replacement of the deteriorated 6-in. carbon steelline, and the slip-lining of the 16-in. CW line with the DN300 HDPE pipe can all be accomplished concurrently with the other subprojects.

Following the subgrade preparation by subproject W-505, the RW and PW lines can be installed around the PC Loop Road, along with the liquid effluent transfer lines (subproject $W-506$ ) and the telecommunication lines (subproject W-503).

\section{Flowmeters}

Provisions will be made to install flowmeters to monitor RW or PW usage by the PCs (see sketch ES-W504-C02). Flowmeters will be installed at the PC points of delivery. The location of the flowmeter will be negotiated with the PC. The type and model of flowmeter to be used in the 200 Area RW and PW systems is unknown, however, turbine type meters are recommended, compatible with Field Data Acquisition System (FDAS) electronic monitoring hardware. Water meters will be furnished with a mechanically-operated impulse contactor for future connections to the FDAS.

\section{Habitat Mitigation}

Habitat mitigation and stabilization of disturbed areas will be provided under subproject W-505.

\section{B. OTHER PROJECT COSTS (900)}

Scanning for underground utilities is provided by subproject W-505. Unknown detected items may require additional exploratory excavations, 
or potholing, to determine their origin. Scanning for two PW lines and scanning for utilities outside the $P C$ site will be provided by subproject $\mathrm{W}-504$.

An allowance for exploratory excavation some of the known lines will be made to verify pipeline location (horizontal and vertical). This is also an opportunity to verify pipeline materials and general configuration of the buried items. This information will be beneficial to the definitive design effort.

Radiation surveys will be required for the various areas being excavated. An allowance for health physics technician (HPT) coverage will be needed to cover the cost of these radiation surveys.

Isolation of the abandoned 16-in. CW pipeline will be verified prior to its use. In addition, a video inspection will be required to verify the condition of the pipeline. The pipeline is critical to design because it provides a clear path through the congested underground portion of the RW route. The CW pipeline serves as an encasement for the DN300 HDPE RW line as it courses north to the tie-in point with the existing 12-in. RW line.

\section{DESIGN COMPLIANCE}

The design and construction of subproject W-504 will comply with the codes and regulations listed in the project DRD.

\section{METHODS OF PERFORMANCE}

The methods of performance comply with the work breakdown structure (WBS)

in Appendix A. The WBS indicates the major phases of work to be accomplished, i.e., engineering, construction, project management, and other project activities. 


\section{A. ENGINEERING (WBS 1.0)}

\section{Definitive Design (WBS 1.1)}

The contracted engineer/constructor contractor will provide definitive design for subproject W-504.

\section{Engineering and Inspection (WBS 1.2)}

The contracted engineer/constructor contractor will provide engineering during construction, acceptance inspection, incorporate contractor as-build/vendor submittals into the Hanford system, oversee walkthroughs and preparation of open items and exception lists, and support contract closing documentation.

\section{B. PROCUREMENT (WBS 2.0)}

N/A

\section{CONSTRUCTION (WBS 3.0)}

Force Account Construction (WBS 3.1)

N/A

Fixed-Price Construction (WBS 3.2)

Construction work will be performed under fixed-price contracts managed and administered by the contracted engineer/constructor contractor.

\section{PROJECT MANAGEMENT (WBS 4.0)}

The performance contractor is directly responsible to the Project Hanford Management Contractor (PHMC) for performing all activities associated with this subproject. The performance contractor will be responsible for the development of overall infrastructure project plans, strategy documents, management of design/construction/startup activities and related PHMC interface activities as well as engineering/technical support. 


\section{E. OTHER PROJECT COSTS (WBS 5.0)}

The performance contractor will direct the resources necessary to perform the expense funded activities (other project costs) needed to implement subproject W-504:

\section{Project Definition (WBS 5.1)}

The performance contractor will provide electrical system integration including interface with the Integrated Product Teams (IPTs) and the Waste Integration Team (WIT), and preparation as well as maintenance of interface control documents (ICDs), and the DRD. Project definition also includes $230 . \mathrm{kV}$ system analysis to the BPA.

\section{Conceptual Design (WBS 5.2)}

The contracted engineer/constructor contractor will prepare a conceptual design report that will provide sufficient details for developing defensible cost estimates and a project schedule.

\section{Project Technical Support (WBS 5.3)}

This task includes the following activities:

- Support the conceptual phase of the project which included the generation of a DRD and a CDR.

- Preparation of an engineering evaluation.

- Performance of unreviewed safety question screening.

- $\quad$ Provide input for integrated schedule.

- Preparation of project management plan.

- Preparation of quality assurance plan.

- Preparation of the safety and environmental documentation. 
- Provide design input and reviews from cognizant plant personnel for definitive design.

- Provide support from plant personnel to generate and coordinate the documents necessary to obtain Washington State Department of Health (WDOH) approval of the design documents.

- Change control and records management support.

- Provide construction support, as required.

- Provide utilities support for system testing and startup including final tie-ins and operational testing.

\section{REQUIREMENTS AND ASSESSMENTS}

A. SAFEGUARDS AND SECURITY

Parts of this project are within the 200-East Limited Security Area potentially requiring security clearance or security escorts. A safeguards and security plan will be provided in accordance with PHMC procedures. This plan will be in effect at the time of construction.

\section{B. HEALTH AND SAFETY}

During the construction period, construction contractors will be required to take all reasonable precautions in their work to protect the health and safety of their employees, subcontractors, operation contractor, and DOE personnel.

All excavation work will be performed in accordance with the Washington Administrative Code (WAC), WAC-296-155, Part N, "Excavation, Trenching, and Shoring." 
The constructor will provide an advance schedule to the patrol and to the fire department. A minimum 24-hr advance notification of any excavation work disrupting any roadway or other services will be required.

Risks associated with construction activities are to be considered and mitigated to the extent practical. In this regard, applicable DOE standards and regulations will be complied with during construction to minimize these risks. A primary hazard in excavating in the 200-East Area is the risk of radioactive contamination and exposure associated with the disposal of radioactive contaminated soil from the pipe trench excavation, and exposure from existing waste transfer lines that are tied into or exposed by project excavation. The appropriate safety standards and procedures for removing, packaging, and disposing of contaminated soil and materials will be followed.

\section{DECONTAMINATION AND DECOMMISSIONING}

No decontamination measures are anticipated for the abandoned 16-in. CW line. The line has been abandoned for several years and no decommissioning plans have been mentioned. By utilizing the $\mathrm{CW}$ line for this project, decommissioning will be postponed indefinitely.

Work required to replace $18 \mathrm{~m}(60 \mathrm{ft})$ of a deteriorated carbon steel PW line may encounter radiation-contaminated soils based upon recent experience. The contaminated soils were limited to a confined area and upon completion of the pipe installation, the radiation-contaminated soils were placed back into the trench as fill material. Decommissioning the abandoned segments of pipe is not required for subproject W-504.

\section{PROVISIONS FOR FALLOUT SHELTERS}

Provisions for fallout shelters are not required for this project. 


\section{E. MAINTENANCE AND OPERATION REQUIREMENTS}

All piping is below grade and, therefore, should require minimal maintenance and have little impact on existing maintenance operations.

\section{F. AUTOMATED DATA PROCESSING EQUIPMENT}

Automated data processing equipment is not required for this project.

\section{G. QUALITY ASSURANCE/SAFETY CLASSIFICATION}

\section{Quality Assurance Activities}

Minimum project quality attributes are included in the project DRD and will be incorporated into the project specific Quality Assurance Program Plan (OAPP). The QAPP will indicate the project critical characteristics, corresponding safety classification assignments, and programmatic controlling documents. The specific technical and quality programmatic requirements, material certifications, qualification and certification of personnel, inspections, examinations and testing, and applicable quality assurance records will be established during definitive design and included in design documents. Specifications will require controls to exclude misrepresented products.

Independent design verification for subproject $\mathrm{W}-504$ will not be required.

\section{Safety Classification}

Safety classifications will be identified for those systems, components, and structures important to safety or environmental protection so that appropriate efforts will be placed on design, procurement, construction, testing, operation, maintenance, and modifications. 
Safety classification criteria and methodology are defined in WHC-CM-4-6, "Non-Reactor Facility Safety Manual." Safety classifications are determined through analysis and consequences of failure based on information contained in the project DRD and safety analysis documents. The resulting safety classifications form the basis for the Hanford design and quality assurance requirements applied to the project. General Services is the highest level anticipated for any element of the proposed RW or PW systems.

\section{H. ENVIRONMENTAL COMPLIANCE}

The design and construction of subproject W-504 will comply with the following environmental regulations:

10 CFR 1021, "National Environmental Policy Act (NEPA)."

36 CFR 800, "Protection of Historical and Cultural Properties."

50 CFR 402, "Interagency Cooperation - Endangered Species Act."

DOE Order 5440.1E, "Compliance with the National Environmental Policy Act."

DOE Order 5484.1, "Environmental Protection, Safety, and Health Protection Information Reporting Requirements."

WAC-173-160, "Minimum Standards For Construction And Maintenance Of Wells; Part Three, Resource Protection Wells."

WAC-246-247, "Radiation Protection-Air Emissions."

Adherence to these regulations ensures that the environmental impacts are understood and properly mitigated, that cultural sites and artifacts are 
identified and protected, that ecological reviews have been completed and mitigation activities identified.

A cultural review of the Phase I Infrastructure development work area was performed and documented. The review determined that cultural sites and artifacts do not exist on the surface and are not expected to be found in the subsurface areas that will be excavated. If, however, artifacts or cultural sites are uncovered or disturbed during excavation or grubbing, work must be halted until the find has been analyzed and properly mitigated.

Installing RW and PW lines are not expected to be sources of toxic air pollutants or radioactive air emissions to the atmosphere. Therefore, air permits for these regulated air emissions are not required. If, however, surface or underground radioactive contamination is discovered during the activities, notification to the WDOH will be required to ensure compliance with WAC-246-247. The WDOH may require a notice of construction (NOC) if underground radioactive material areas are discovered.

\section{l. PERMITS}

The WDOH may require a NOC if underground radioactive material areas are discovered during subproject W-504 activities. The construction activities will require a Washington State Waste Discharge Permit for Hydrotesting Maintenance and Construction, Permit No. ST 4508. The PW system design will require approval by the State of Washington.

\section{J. UNREVIEWED SAFETY QUESTION}

(See Appendix G).

\section{K. POLLUTION PREVENTION/WASTE MINIMIZATION}

Beginning January 1, 1997, all new projects having an estimated value at a General Plant Project level or higher and entering into conceptual design 
will utilize a checklist to document that pollution prevention/waste minimization (P2NMin) has been considered in the development of the design package.

Through the use of microcomputer program P2-EDGE (ref 8), a P2NMin opportunities list was prepared for subproject $W-504$. The list identifies those P2/WMin opportunities that are to be implemented and/or considered for further evaluation throughout the design and construction process.

A design checklist was developed during conceptual design that documents the evaluation of the items identified in the P2/WMin opportunities list for implementation and/or consideration. Sound engineering judgment based on experience was employed to determine those P2NMin opportunities that will be implemented into the design and/or construction activities, and when. The P2/WMin opportunities list summary report and the design checklist are shown in Appendix $K$.

\section{IDENTIFICATION AND ANALYSIS OF UNCERTAINTIES}

\section{A. POTABLE WATER}

\section{Underground Interferences}

The proposed location of the PW line has not been scanned for existing underground interferences. Undetermined utility lines may alter the anticipated routes.

\section{Potential for Contaminated Soil}

Efforts have been made to route the proposed PW line improvements away from areas of radioactive or hazardous waste contamination. However, adjacent to 275-EA and the 241-C Tank Farm, subsurface contamination may exist and the areas need to be scanned and monitored for radiation prior to and during construction. 
Water Supply Flow, Pressure, and Quality

RL has committed contractually to supply each PC with 95 lpm (25 gpm) per PC (24-hr average) or a total of $190 \mathrm{lpm}(50 \mathrm{gpm})$. In comparison, the DRD has specified that a total of $245 \mathrm{lpm}$ (65 gpm) (24-hr average) will be used for design when determining the size of the water supply piping. A cursory review of the hydraulics indicate that the existing PW system can supply $735 \mathrm{lpm}(195 \mathrm{gpm})$ peak flow demand at a minimum pressure of $483 \mathrm{kPa}$ (70 psi). This is based on the DRD figure, $245 \mathrm{lpm}$, with a peaking factor of 3 for a maximum flow condition. A water balance analysis is recommended at initiation of definitive design to verify the available flow and pressure.

Though the design appears conservative, there is a concern for flow stagnation in the PW system. The supply main may require a chlorine injection system to maintain water quality. A review of this concern during definitive design is prudent.

\section{B. RAW WATER}

\section{Underground Interferences}

The proposed location of the RW line has not been scanned for existing underground interferences. Undetermined utility lines may alter the anticipated location.

\section{Condition of the Abandoned 16-in. CW Pipeline}

The CW pipeline has been abandoned and out of service for several years. Using the line as a host pipe for the HDPE is of concern. The following actions should be taken in the interim prior to the start of definitive design. 
- Verify that the south end of the line has been blanked-off with a blind flange as shown in 241-A-201 valve pit on drawing $\mathrm{H}-2-55996$. Determine if access can be made at this location to insert a video camera for inspection purposes.

- Verify that the north end of the line has been isolated. Other than valving in the 241-A-401 and 241-A-501 Buildings, isolation of the line has not been verified. Reference drawings $H-2-56129$, $\mathrm{H}-2-56789$, and $\mathrm{H}-2-56789$.

- The condition of the inside surface has not been verified. The $\mathrm{CW}$ line may be filled with water. Due to corrosion and rust buildup, the inside surface of the pipe may have to be cleaned and smoothed to avoid damaging the HDPE pipe during installation.

- An allowance for performing potholing, to gain entry into the $\mathrm{CW}$ pipeline for video inspections is recommended should other avenues of entry prove to be impractical or not available.

- In the process of performing the above evaluations, verify if the existing $\mathrm{CW}$ pipe or the contents within it are radioactively contaminated.

\section{Potential for Contamination}

Efforts have been made to route the proposed RW line improvements away from areas of radioactive contamination. However, with the proposed RW being adjacent to the 242-A Evaporator and the 216-A-8, 216-A-30, and 216-A-37-2 cribs and within the existing 16-in. CW pipeline, subsurface contamination may exist. Since there is a reasonable potential for contamination, core samples of the soil are recommended to assess the soil conditions. 
Water Supply Flow and Pressure

RL has committed contractually to supply $760 \mathrm{lpm}(200 \mathrm{gpm})$ to each PC (24-hr average) of process RW or a total of $1520 \mathrm{lpm}(400 \mathrm{gpm})$ and provide up to a total of $9450 \mathrm{lpm}(2500 \mathrm{gpm})$ of fire water to be shared between the PCs. In comparison, the DRD has combined the needs of both PCs requiring a total of $1090 \mathrm{lpm}(290 \mathrm{gpm})$ (24-hr average) and matching the fire flow noted above, but adding a minimum $345 \mathrm{kPa}$ (50 psi) for minimum duration of 4 hours. The pipe size will be DN300 (12 in.) as governed by National Fire Protection Agency (NFPA) 24, DOE Order 6430.1A, and RL Implementing Directive (RLID) 5480.7. A preliminary water balance analysis was performed which resulted favorably in satisfying the design requirements (ref 9).

\section{Detrimental Effects of DN200 Inter-tie}

The preliminary RW system analysis was performed to determine the system capability. Recommendations within this analysis find that improved flow conditions will occur if a DN200 RW inter-tie is made east of the 241-AX Tank Farms. Based on this recommendation, the LOI requests that this inter-tie be made part of subproject W-504. However, reservations have been expressed about making this connection. Questions exist regarding the location and integrity of the $40-y r$ old pipeline. Drawings indicate that schedule 40 carbon steel was originally installed. Making this tie-in and subjecting the old line to reverse flow conditions may have detrimental affects on the old line. The consequence of making this tie-in connection may result in replacing the existing line, in part or in its entirety, earlier than previously planned.

In addition, the soil conditions and underground interferences where the crossing will be made are suspect. The potential for finding contaminated soils is high and the presence of the 36-in. CMP liquid effluent drain line complicates this connection. The added benefit of making this connection may be outweighed by the risk it suggests to the existing pipeline. 


\section{c. CONTROL OF CONTAMINATED SOILS}

During soil excavations, hazardous or radioactive-contaminated soils may be encountered. If rerouting or realigning to avoid the contaminated site is impracticable, removal of the contaminated soil will to be addressed on a case-by-case basis. Handling contaminated soils will have an adverse impact to the cost and schedule of the project.

The cost and schedule impacts will be governed by the level of contamination. The safety and procedural methods used in response to handling contaminated materials are determined by the source. What additional resources will be required are impossible to predict. However, there are costs associated with the handling, packaging, and the burial costs, and the monitoring support from the HPT. A contingency will be added to cover cost and schedule impacts resulting from delays caused by special dress requirements, packaging excavated material, coordinating the transportation of packaged waste using regulated vehicles, etc. The level of contamination will remain unknown until a radiological assessment can be completed.

\section{REFERENCES}

\section{A. DOCUMENTS}

1. Letter of Instruction No. 2, Subproject W-504, Tarik Choho (Numatec Hanford Corporation) to J. L. Henderson (Fluor Daniel Northwest), "TWRS Privatization Phase I Raw and Sanitary Water," NHC-9750683, January 31, 1997.

2. Letter of Instruction No. 3, Subproject W-504, R. J. Parazin (Numatec Hanford Corporation) to B. C. Harmon (Fluor Daniel Northwest), "TWRS Privatization Phase I Raw and Sanitary Water," NHC-9752787, March 31, 1997. 
3. Site Evaluation Report, "Tank Waste Remediation System Privatization Phase I Site Evaluation Report," WHC-SD-WM-SE-023, Rev. OA, prepared by Westinghouse Hanford Company, January 1996.

4. Contract, "TWRS Privatization Contract," British Nuclear Fuels Limited (BNFL), DE-AC06-96RL13308, 1996.

5. Contract, "TWRSPrivatization Contract," Lockheed Martin Advanced Engineering Services (LMAES), DE-ACO6-96RL13309, 1996.

6. Design Requirements Document, "TWRS Privatization Phase I Raw and Potable Water Supply Systems," WHC-SD-WM-DRD-015, Rev. 0, prepared by ICF Kaiser Hanford Company, September 1996.

7. Engineering Study, "TWRS Privatization Phase I Raw and Potable Water Service Engineering Study," WHC-SD-TWR-ES-002, Rev. 0, prepared by Westinghouse Hanford Company, September 1996.

8. Microcomputer Program P2-EDGE, Version 2.0, "Pollution Prevention Environmental Design Guide for Engineers," Pacific Northwest National Laboratory, 1996.

9. Letter Report, "Tank Waste Remediation System Privatization Phase I, Water Balance Analysis," E23385LR, prepared by ICF Kaiser Hanford Company, September 1996.

10. Interface Control Document, "Interface Control Document for Raw Water," WHC-SD-WM-ICD-034, Rev. 0, prepared by Westinghouse Hanford Company, January 1996. 
11. Interface Control Document, "Interface Control Document for Potable Water," WHC-SD-WM-ICD-035, Rev. 0, prepared by Westinghouse Hanford Company, January 1996.

\section{B. CODES AND STANDARDS}

\section{Code of Federal Regulations}

10 CFR 1021, "National Environmental Policy Act Implementing Procedures."

36 CFR 800 , "Protection of Historical and Cultural Properties."

50 CFR 402, "Interagency Cooperation - Endangered Species Act."

\section{U.S. Department of Energy Orders}

DOE Order 5440.1E, "Compliance with the National Environmental Policy Act."

Order 5484.1, "Environmental Protection, Safety, and Health Protection Information Reporting Requirements."

Order 6430.1A, "General Design Criteria."

\section{Washington Administrative Code}

WAC-173-160, "Minimum Standards For Construction And Maintenance Of Wells; Part Three, Resource Protection Wells."

WAC-246-247, "Radiation Protection-Air Emissions."

WAC-296-155, "Safety Standards for Construction Work." 
HNF-SD-W504-CDR-001, Rev. 0

\section{DRAWINGS}

H-2-32981, Sh. 1, Rev. $1 \quad 3$ in. Sanitary Water Line to 241-AX

H-2-34505, Sh. 1, Rev. 1 Civil Water Supply Sludge Transfer Facilities for Tank 241-A-101

H-2-34874, Sh. 1, Rev. 5 Fire Hydrant Map, 200 East

H-2-36535, Sh. 1, Rev. 18 Sanitary \& Raw Water Map, 200-East Area

H-2-36535, Sh. 7, Rev. 1 Sanitary \& Raw Water Map, 200-East Area

H-2-36535, Sh. 8, Rev. 0 Sanitary \& Raw Water Map, 200-East Area

H-2-36535, Sh. 10, Rev. 2 Sanitary \& Raw Water Map, 200-East Area

H-2-43409, Sh. 1, Rev. 23 in. Sanitary Water 241-C Tank Farm

H-2-55900, Sh. 1, Rev. 9 Plot Plan

H-2-55993, Sh. 1, Rev. 316 in. Cooling Water Line Plan \& Profile PUREX Waste Disposal Facility

H-2-55994, Sh. 1, Rev. 48 in. Raw Water Plan \& Profile PUREX Waste Disposal Facility

H-2-55994, Sh. 2, Rev. 48 in. Raw Water Plan \& Profile PUREX Waste Disposal Facility

H-2-55995, Sh. 1, Rev. 316 in. Cooling Water \& 8 in. Raw Water Section \& Details 
H-2-55996, Sh. 1, Rev. $4 \quad 750,000$ gal. Cooling Water Storage Tank Contractor Information

H-2-56038, Sh. 1, Rev. 4 Control House 241-A-271 Equipment Arrangement \& Piping

H-2-56114, Sh. 1, Rev. 1 Contact Condensed Installation Plot Plan

H-2-56115, Sh. 1, Rev. 2 Contact Condensed Installation General Layout

H-2-56121, Sh. 1, Rev. 2 Control Valve Pit Structural

H-2-56125, Sh. 1, Rev. 4 Vapor Header Condenser Arrgt

H-2-56126, Sh. 1, Rev. 4 Contact Condenser Installation Water Supply \& Drain Piping-Arrgt

H-2-561 29, Sh. 1, Rev. 7 Contact Condenser 241-A-501 Valve Pit Piping Arrangement

H-2-56135, Sh. 1, Rev. 1 Extension of 8 in. Raw Water \& 16 in. Cooling Water Plan \& Profile

H-2-56395, Sh. 1, Rev. 0 Temporary Construction Water Line Locations "As Built"

H-2-56789, Sh. 1, Rev. 416 in. Cooling Water Plan \& Profile to 241-A-401 Condenser

H-2-56797, Sh. 1, Rev. 1 241-A-401 Waste Cooling Water Plan \& Profile 
H-2-57285, Sh. 1, Rev. 4

H-2-61974, Sh. 1, Rev. 2

H-2-61975, Sh. 1, Rev. 2

H-2-69267, Sh. 1, Rev. 6

H-2-69288, Sh. 1, Rev. 1
241-A-401 Equipment Arrangement Plan

Civil Plan \& Profile 6 in. San. Water Ln. No. $850 \& 8$ in. Raw Water Ln. No. 849

216-A-41 Crib, Plan \& Profile of 6 in. San. Water Ln. No. $850 \& 8$ in. Raw Water Ln. No. 849

Civil Plot Plan

Civil 4 in. Sanitary \& 14 in Raw Water Plan, Profile \& Details

H-2-71902, Sh. 1, Rev. 1 Civil Site Preparation Plan 241-AN Tank Farm

H-2-72414, Sh. 2, Rev. 3 Civil Site Plan Profiles and Details

H-2-76481, Sh. 1, Rev. 2 Piping Plan Raw \& Sanitary Water

H-2-76481, Sh. 2, Rev. 2 Piping Plan Raw \& Sanitary Water

H-2-81238, Sh. 1, Rev. 3 Sanitary and Raw Water Systems Routing Plan

H-2-81238, Sh. 2, Rev. 3 Sanitary and Raw Water Systems Routing Plan

H-2-81238, Sh. 3, Rev. 3 Sanitary and Raw Water Systems Routing Pian 
H-2-81238, Sh. 4, Rev. 3

H-2-88720, Sh. 1, Rev. 1

H-2-88722, Sh. 1, Rev. 1

H-2-88723, Sh. 1, Rev. 2

H-2-88724, Sh. 1, Rev. 1

H-2-88724, Sh. 2, Rev. 1

H-2-88725, Sh. 1, Rev. 2

H-2-88726, Sh. 1, Rev. 2

H-2-88727, Sh. 1, Rev. 1

H-2-88728, Sh. 1, Rev. 1

H-2-88728, Sh. 2, Rev. 0

H-2-88729, Sh. 1, Rev. 1

H-2-88729, Sh. 2, Rev. 1 Civil Details
Civil Plan/Profile and Details 12" Fire Water

Civil Details

Sanitary and Raw Water Systems Routing Plan

Key Plan and Drawing List 12" Fire Water and 4" Sanitary Water

Civil Plan/Profile and Details 242A Tie-in

Civil Plan/Profile 12" Fire Water \& 4" SW Lines

Civil Plan/Profile 12" Fire Water \& 4" SW Lines

Civil Plan/Profile 12" Fire Water \& 4" SW Lines

Civil Plan and Details 12" Fire Water \& 4" SW Lines

Civil Profiles 12" Fire Water \& 4" SW Lines

Civil Plan/Profile 12" Fire Water

Civil Plan/Profile 12" Fire Water 
H-2-88729, Sh. 3, Rev. 0 Civil Details

H-2-131002, Sh. 1, Rev. 0 Civil Project Site Plan

H-2-131003, Sh. 1, Rev. O Civil Bldg. Site Plan

H-2-131004, Sh. 1, Rev. 0 Civil Plan \& Profile Raw Water 


\title{
APPENDIX A
}

\author{
Work Breakdown Structure
}




\section{WORK BREAKDOWN STRUCTURE}

\subsection{ENGINEERING}

1.1 Definitive Design (Contracted Engineer/Constructor Contractor).

1.2 Engineering and Inspection (Contracted Engineer/Constructor Contractor)

2.0 PROCUREMENT (N/A)

3.0 CONSTRUCTION

3.1 Force Account Construction (N/A)

3.2 Fixed-Price Construction (Construction Contractor)

4.0 PROJECT MANAGEMENT (Performance Contractor)

5.0 OTHER PROJECTS COSTS (Expense Funded)

5.1 Project Definition (Performance Contractor)

5.2 Conceptual Design (Contracted Engineer/Constructor Contractor)

5.3 Project Technical Support (Performance Contractor) 


\title{
APPENDIX B
}

\author{
Budget AuthorizediBudget Outlay Schedile
}


SUB-PROJECT W-504

TWRS PRIVATIZATION PH. I RAW AND SANITARY WATER SYSTEMS

BA / BO SCHEDULE

\subsection{ENGINEERING}

1.1 DEFINITIVE DESIGN

1.2 E / DURING CONST

$\underset{1}{1}$

\subsection{CONSTRUCTION}

3.2 FIXED PRICE CONST.

4.0 PROJ MANAGEMENT

5.0 OTHER PROJ COSTS

TOTALS BA/BO

DOLLARS IN THOUSANDS

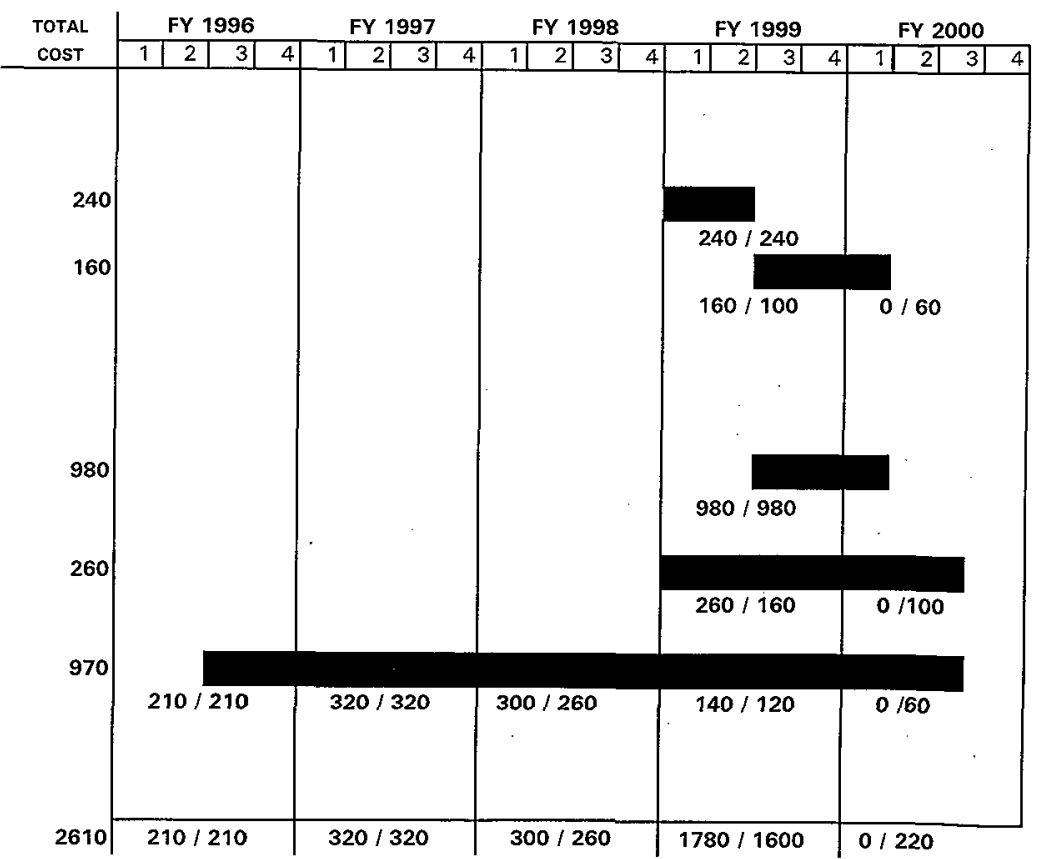




\title{
APPENDIX C
}

\author{
Cost Estimate Summary.
}




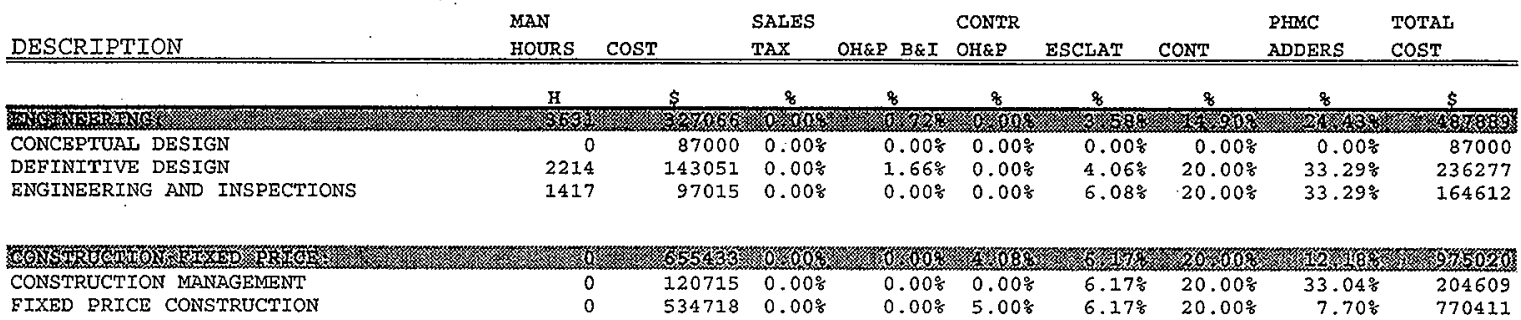

WEF

ThW

275

$0.00 \% \quad 10.00 \%$

$0.00 \%$

262392

PROJECT DEFINITION

$1460 \quad 292106 \quad 0.00 \%$

20.

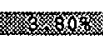

20.6038

PROJECT TECHNICAL SUPRORT

10783

$\$ 2,067,946 \quad 0.00 \%$

$0.11 \% \quad 1.29 \%$

$0.00 \% \quad 3.70 \%$

$0.00 \% \quad 302916$

SUB-TOTAL PROJECT COST

ADJOSTED/ROUNDED

$(12,501)$

TOTAL PROJECT COST

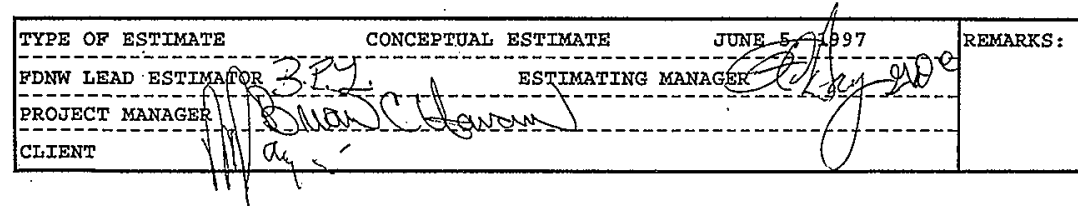


FLUOR DANIEL NORTRWEST, INC. NUMATEC HANFORD CORP JOB NO. W504/P2GE08

FILE NO H504BAA3

WBS DESCRIPTION

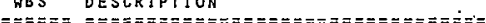

110000 DEFIMITIVE DESIGN

120000 ENGINEERIMG ANO INSPECTIOH

SUBTOTAL 1 ENGINEERING

324001 B.TH STREET SW WATERLINE CO \#6

324002 275-EA BLDG SW LINE REPAIR CO\#7

324003 HDPE PIPE IN EXISIING LINER CO\#3/\#4

$3240044^{\prime \prime}$ SANITARY HATERLIHE CO\#2/\#5

$32400512 "$ RAH HATER 100 P

324006 8" RAW WATER GROSS TIE

SUBTOTAL $324 \quad W-504$ FP CONSTRUCTION COSTS

SUBTOTAL 3 CONSTRUCTION

I 400000 PROJECT MANAGEMENT

SUBTOTAL 4 PROJECT MAMAGEMENT

510000 PROJECT DEFINITION

520000 CONCEPTUAL DESIGH

530000 PROJECT TECHHICAL SUPPORT

SUBTOTAL 5 OTHER PROJECT COSTS

PROJECT TOTAL
* * IEST * INTERACTIVE ESTIMATING ** THRS PRIVATIZATION PHASE I RAH AMD SANITARY WATER CONCEPTUAL ESTIMATE

PHMCRO2 - WORK BREAKDOWN STRUCTURE (WBS) SUMHARY
PAGE 2 OF 13

DATE $06 / 05 / 97 \quad 06: 14: 36$

BY KLR/BPL

\begin{tabular}{|c|c|c|c|c|c|c|c|c|}
\hline $\begin{array}{l}\text { ESTIMATE } \\
\text { SUBTOTAL } \\
======\end{array}$ & $=\begin{array}{c}E S C S \\
\% \\
===\end{array}$ & $\begin{array}{l}\text { LATIOM } \\
\text { TOYAL } \\
======\end{array}$ & $\begin{array}{c}\text { SUB } \\
\text { TOTA } \\
====\equiv===\end{array}$ & $\begin{array}{c}c 0 N T \\
\% \\
==\end{array}$ & $\begin{array}{l}\text { NGENCY } \\
\text { VIOTAL } \\
======\end{array}$ & $\begin{array}{c}\text { SUB } \\
\text { TOTAL } \\
=====\equiv==\end{array}$ & $\begin{array}{c}\text { SITE } \\
\text { A LLOCAT'A } \\
=======\end{array}$ & $\begin{array}{c}\text { TOTAL } \\
\text { DOLLARS } \\
=======\end{array}$ \\
\hline $\begin{array}{r}145422 \\
97015\end{array}$ & $\begin{array}{l}4.06 \\
6.08\end{array}$ & $\begin{array}{l}5904 \\
5901\end{array}$ & $\begin{array}{l}151326 \\
102916\end{array}$ & $\begin{array}{l}20 \\
20\end{array}$ & $\begin{array}{l}30265 \\
20583\end{array}$ & $\begin{array}{r}181591 \\
\cdot 123499\end{array}$ & $\begin{array}{l}54685 \\
41112\end{array}$ & $\begin{array}{l}236277 \\
164612\end{array}$ \\
\hline 242437 & 4.87 & 11805 & 254242 & 20 & 50848 & 305090 & 95798 & 400889 \\
\hline $\begin{array}{r}67060 \\
13397 \\
53327 \\
118915 \\
405055 \\
24423\end{array}$ & $\begin{array}{l}6.17 \\
6.17 \\
6.17 \\
6.17 \\
6.17 \\
6.17\end{array}$ & $\begin{array}{r}4137 \\
826 \\
3290 \\
7337 \\
24991 \\
1506\end{array}$ & $\begin{array}{r}71198 \\
14224 \\
56617 \\
126252 \\
430047 \\
25930\end{array}$ & $\begin{array}{l}20^{\circ} \\
20 \\
20 \\
20 \\
20 \\
20\end{array}$ & $\begin{array}{r}14239 \\
2844 \\
11323 \\
25250 \\
86009 \\
5186\end{array}$ & $\begin{array}{r}85438 \\
17069 \\
67941 \\
151503 \\
516056 \\
31117\end{array}$ & $\begin{array}{r}10409 \\
2079 \\
8278 \\
18459 \\
62876 \\
3791\end{array}$ & $\begin{array}{r}95847 \\
19149 \\
76219 \\
169962 \\
578933 \\
34908\end{array}$ \\
\hline 682181 & 6.17 & 42090 & 724271 & 20 & 144854 & 869126 & 105894 & 975020 \\
\hline 682181 & 6.17 & 42090 & 724271 & 20 & 144854 & 369126 & 105894 & 975020 \\
\hline 238539 & 0.00 & 0 & 238539 & 10 & 23853 & 262392 & 0 & 262392 \\
\hline 238539 & 0.00 & 0 & 238539 & 10 & 23853 & 262392 & 0 & 262392 \\
\hline $\begin{array}{r}292106 \\
87000 \\
554802\end{array}$ & $\begin{array}{l}0.00 \\
0.00 \\
0.00\end{array}$ & $\begin{array}{l}0 \\
0 \\
0\end{array}$ & $\begin{array}{r}292106 \\
87000 \\
554802\end{array}$ & $\begin{array}{l}4 \\
0 \\
5\end{array}$ & $\begin{array}{r}10810 \\
0 \\
29480\end{array}$ & $\begin{array}{r}302916 \\
87000 \\
584282\end{array}$ & $\begin{array}{l}0 \\
0 \\
0\end{array}$ & $\begin{array}{r}302916 \\
87000 \\
584282\end{array}$ \\
\hline 933908 & 0.00 & 0 & 933908 & 4 & 40290 & 974198 & $0^{\circ}$ & 974198 \\
\hline 997,065 & $z: 57$ & 53,895 & $2,150,961$ & 12 & 259,847 & $2,410,808$ & 201,693 & $\begin{array}{l}==\pi=== \\
2,612,50\end{array}$ \\
\hline
\end{tabular}


FLUOR DAHIEL NORTHWEST, INC. NUMATEC HANFORD CORP JOB NO. H5O4/P2GEOB

FILE NO. H5O4BAA3

1. ESTIMATE PURPOSE

CONCEPTUAL COST ESTIMATE: THIS ESTIMATE HILL BE USEO TO ESTABLISH THE PROJECT BUDGET(BASELINE).

2. ESTIHATE TECHNICAL BASIS

A. THIS ESTIHATE HAS BEEN PREPARED FOR THE W-504 PROJECT AS REQUESTED 8Y FONH PROJECT MANAGEMENT AND NUMATEC HANFORD INC.

B. A DESCRIPTION OF THE TECHNICAL SCOPE OF HORK MAY BE FOUHD IN THE FOLLOWING REFERENCE DOCUMENTS:

REQUEST FOR ESTIMATE DATED 3/20/97, COR HWF-SD-W504-CDR-0O1 REVISION O DATED JUNE 1997 .

C. THIS ESTIMATE UTILIZES AN ESTIMATE HORK BREAKDOWN STRUCTURE WHICH INTERFACES WITH THE PROJECT WORK BREAKOOWN STRUCTURE AS PROVIDED BY PROJECT MAMAGEMENT/PROJECT COUTROLS.

3. ESTIMATE HETHODOLOGY

A. DIRECT COSTS:

A BOTTOMS-UP TECHHIQUE HAS BEEN UTILIZED IN THE PREPARATION OF THIS ESTIMATE.

(1) CONSTRUCTION LABOR, MATERIAL AND EQUIPMENT UNITS HAVE BEEN ESTIHATED BASED UPON ONE OR MORE OF THE FOLLOHING STANOARD COMMERCIAL ESTIMATING RESOURCES, PUBLISHED ESTIMATING MANUALS/.DATABASES: IN HOUSE DATABASES

THE UAITS MAY HAVE BEEN FACTORED/ADJUSTED BY THE ESTIMATOR AS APPROPRIATE TO REFLECT INFLUEYCES BY CONTRACT HORK SITE, OR OTHER IDENTIFIED PROJECT OR SPECIAL CONDITIONS.

(2) THE DIRECT COST FOR FLUOR DAHIEL HANFORD AND HUMATEC TAVE

BY HBC PROJECT HANAGEMENT FOR INCLUSION INTO THIS ESTIMATE

DIRECT COST FACTORS

(1) SALES TAX HAS BEEN APPLIED TO ALL MATERIALS AND EQUIPMENT PURCHASES AT $8 \%$.

(2) CONTRACT ADMINISTRATION FACIOR OF 21.5\% HAS BEEN APPLIED TO THE DIRECT CONTRACT VALUE WHICH INCLUDES COSTS FOR BIO PRCKAGE PREPARATION, CONTRACT MANAGEMENT \& AOHINISTRATION AND PLANMING SUPPORT.

(3) A FACTOR OF 0.25\% FOR HOME OFFICE ENGINEERING TO ALLOH FOR USAGE OF GOVERNMENT OHNED EQUIPMENT CONTROLLED BY DYNCORP.

c. INDIRECT COSTS

FIXEO PRICE CONTRACTOR COSTS ARE UNIT PRICE THEY APPEAR IN SUBCONTRACT COLUMN AND INCLUDE CONTRACTORS OH\&P.

D. RATES

(1) FLUOR DANIEL NORTHWEST LABOR RATES ARE BASED UPON THE FLUOR DANIEL FEDERAL OPERATIONS (FEOFO) OISCLOSURE STATEMENT. FOR ESTIMATING PURPOSES, AVERAGE RATES BY OPERATIONS CODE HAVE BEEN DEVELOPED BASED UPOH RECENT COST GISTORY.

E. SITE ALLOCATIONS FACTORS

SITE ALLOCATION FACTORS ARE DEVELOPED AND PROVIOED BY FLUOR DANIEL HANFORD (EOH) FOR .ESTIMATING USE.

(1) GOVERHMENT FURNISHED SERVICES RATE IS APPLIED TO ALL COSTS TO LIQUIDATE GOVERNMENT FURHISHED SERVICES PROVIDED TO THE ENTERPRISE COMPANIES: $14 \%$ FOR FDNH.

(2) HANFORD SITE G\&A RATE OF $16.7 \%$ IS APPLIED TO ALL COSTS TO LIQUIDATE THE HAMFORD GENERAL \& ADMINISTRATIVE COSTS.

(3) HANFORD SITE MPR RATE OF $7.0 \%$ IS APPLIED TO ALL PURCHASED MATERIAL AND $7.7 \%$ TO ALL PURCHASED SERVICES TO LIQUIDATE THE COST OF PROCUREHERT (INCLUDING RECEIVING). 
FLUOR DANIEL NORTHWEST, INC. NUMATEC HAHFORD CORP

JOB HO H5O4/P2GEOB

FILE NO. W5O4BAA3
** IEST - INTERACTIVE ESTIMATING **

TURS PRIVATIZATION PHASE I RAH ANO SAHITARY HATER CONCEPTUAL ESTIMATE

PHMCRO3. ESTIMATE BASIS SHEET
PAGE 4 OF 13

OATE $06 / 05 / 97 \quad 14: 13: 17$

BY KLR/8PL

FDNH APPLIES THE ABOVE FACTORS TO ESTIHATED COSTS AS FOLLOHS

(1) FDH GFS/G\&A CM FACTOR: A COMPOSITE FACTOR OF $33.04 \%$ HAS BEEN APPLIED TO TOTAL FDNH FIXED PRICE CONSTRUCTION MANAGEMENT WHICH INCLUDES GOVERNMENT FURHISHED SERVICES (GFS) AND SITE G\&A/FEE.

(2) FDH CN RATE FP CONST FACTOR: A MATERIAL G\&A/FEE RATE FACTOR OF 7.7\% HAS BEEM APPLIED TO THE FDNW FIXED PRICE CONSTRUCTION CONTRACT VALUE.

(3) FDH GFS/G\&A LABOR FACTOR: A COMPOSITE FACTOR HAS BEEN APPLIED TO TOTAL FDUW LABOR COSTS AS FOLLOWS: $A E / C H$ COSTS $=33.04 \%$, FDNWS CONSTRUCTION MANAGEMENT LABOR $=.33: 04 \%$.

4. ESCALATION

ESCALATION PERCENTAGES HERE CALCULATEO FROM THE JAHUARY 1997 UPDATE OF THE ECONOMIC ESCALATION PRICE CHANGE INDICES FOR DOE CONSTRUCTION PROJECTS AS PUBLISHED BY THE "OFFICE OF INFRASTRUCTURE ACQUISITIONMFM-5O.

5. CONIINGENCY

A. DEFINITION OF CONTINGENCY AS PROVIDED $8 Y$ DOE:

"CONTINGENCY COVERS COSTS THAT MAY RESULT FRON INCOMPLETE DESIGN, UNFORESEEN AND UNPREDICTABLE CONDITIONS, OR UNCERTAINTIES WITHIM THE DEFINED PROJECT SCOPE. THE AMOUNT OF CONTINGENCY WILL DEPEND ON THE STATUS OF DESIGM PROCUREMENT, AHD CONSTRUCTION; AND THE COMPLEXITY AND UNCERTAINTIES OF THE COMPONENT PARTS OF THE PROJECT. CONTINGENCY IS NOT TO BE USED TO AVOID MAKING AM ACCURATE ASSESSMENT OF EXPECTED COST" (OFFICE OF HASTE MANAGEMENT (EM-3O) COST AND

$P$ B. CONTINGENCY ALLOWANCE GUIDELINES:

THE DOE GUIDELINE CONTINGENCY ALLOWANCE FOR A CONCEPTUAL ESTIMATE - STANDARD= $15 \%$ TO $25 \%$.

6. METHODOLOGY

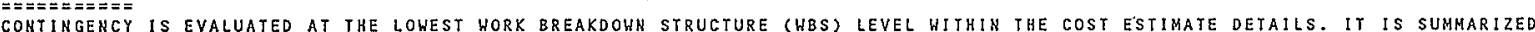
CONTINGENCY IS EVALUATED AT THE LOWEST HORX BREAKDOWN STRU

7. ANALYSIS

$=\pi= \pm \#==$

AH ASSESSMENT OF DESIGN MATURITY, WORK COMPLEXITY AND PROJECT UNCERTAINTIES HAS BEEN PERFORMED. AN EXPLANATION OF TRIS ASSESSMENT AND CONTINGENCY RATES WHICH HAVE BEEN ADDED TO THE COST OF WORK ARE AS FOLLOWS:

W8S 1.1. A CONTINGENCY OF $20 \%$ HAS BEEN APPLIED DUE TO THE PRELIMINARY STAGE OF DESIGN.

WBS 1.2. A CONTINGENCY OF 20\% HAS BEEH APPLIED BECAUSE THE PERCENTAGE USED WAS TAKEN OFF OF CONSTRUCTION DIRECT DOLLARS. SEE COMMENTS ON W.B.S. 32

WBS 3.2. A CONTINGENCY OF 20\% HAS BEEN APPLIED DUE TO THE PRELIMIMARY STAGE OF DESIGN AND UN.CERTAENTY CONCERMIMG UNDERGROUND OBSTRUCTIONS WITHIN THE UTILITY CORRIDOR.

HBS 4.0. A CONTINGENCY OF $10 \%$ HAS BEEN APPLIEO PER CLIENT REQUEST.

WBS 5.1. A CONIINGENCY OF $4 \%$ HAS BEEN APPLIEO PER CLIENT REQUEST.

WBS 5.2. A CONIINGENCY OF $0 \%$ KAS BEEN APPLIED BECAUSE CONTINGENCY IS INCLUDED IN THE COST

HBS 5.3. A. CONTINGENCY OF $5 \%$ HAS BEEN APPLIED PER CLIENT REQUEST. 
FLUOR OANIEL NORTHHEST, INC. NUMATEC HANFORD CORP JOB NO. W504/P2GEOS

FILE NO. H504BAA3
** IEST - INTERACTIVE ESTIMATING * *

TWRS PRIVATIZATION PHASE I RAH AMD SANITARY WATER CONCEPTUAL ESTIMATE

PHMCRO3. ESTIMATE BASIS SHEET
PAGE 5 OF 13

DATE $06 / 05 / 97 \quad 14: 13: 17$

BY KLR/BPL

\section{ROUNDING}

THE PROJECT COST SUMMARY REPORT IS SUMMARIZED AND ADJUSTEO/ROUNDED AS FOLLOWS:

THE ESCALATED TOTAL COST COLUMN, CONIINGENCY TOTAL COLUMN AND TOTAL DOLLARS COLUMH SUB - TOTALS ARE SUMMARIZED BY CATEGORIES. THE TOTAL PROJECT COST ARE ADJUSTED/ROUNDED TO THE NEAREST \$10,000/\$100,000.

\section{REMARKS}

PER THE OIRECTION OF THE CUSTOHER (NUMATEC HANFORD INC.), THE PROJECT SUMMARY SHEET WAS MODIFIED TO REFLECT DISTRIBUTION OF COSTS BY ACTIVITY. (I,E. ENGINEERING, CONSTRUCTION, AND PROJECT MANAGEMENT)

MAJOR ASSUMPTIONS WHICH BAVE BEEN MADE IN THE PREPARATION OF THIS ESTIMATE ARE AS FOLLOWS:

A.) ALL CONSTRUCIION HORK IS TO BE DONE BY FIXED PRICE CONTRACTOR

B.) \& I WERE ESTINATED AS A DIRECT PERCENTAGE OF CONSTRUCTION.

C.) FDNH PROJECT MANAGEMENT ANO DEFINITIVE DESIGN HERE MANLOADED BY FDNW PROJECT MANAGEMENT.

D.) PORTIONS OF PROJECT W-505 MUST BE COMPLETED IN CONJUNCTION WITH THIS PROJECT.

E.) ALL NUMATEC COSTS WERE PROVIDED BY FDNW PROJECT MANAGEMENT AND NUMATEC HANFORD INC.

F.) OTHER PROJECT COSTS FOR PRIOR YEARS (FY96 AND FY97) ARE BASED ON ACTUAL EXPENDITURES, FISCAL YEAR 97 BUDGETS AND ESTIMATES TO COMPLETE. FISCAL YEARS 98, 99, 00 AND 01 REFLECT THE LATEST INFORMATION FROM DESIGN REQUIREMENTS DOCUMENTS, STUDLES, ARD PLANS COMPLETEO TO OATE. COST PROVODED BY NUMATEC FOR HBS $4.0,5.1,5.2$, AND 5.3 ARE INCLUSIVE OF ESCALATION AND APPLICABLE TAXES PER NHC PROJECT MANAGEHENT.

THE MUMATEC PROJECT MANAGERS EXPERTISE AND EXPERIENCE WITH PREVIOUS PROJECTS, THE PREVIOUSLY COMPLETED

LIFE CYCLE COST ESTIMATE, AND HISTORICAL DATA FROM PREVIOUSLY COMPLETED PROJECTS HAVE BEEN USED TO DERIVE

THE ESTIMATED COSTS. DETAILED PLANNING FOR THESE ACTIVITIES WILL BE REFLECTED IN THE PHMC FY9B MULII YEAR WORK PLAN. 
FLUOR DANIEL NORTHHEST, IHC. NUMATEC HANFORD CORP JOB NO. WSO THRS PRIVATIZATION PHASE I RAW AND SANITARY HATER CONCEPTUAL ESTIMATE

PHMCRO5 - CONSTRUCTION MANAGEMENT/OTHER COST SUMMARY

WBS DESCRIPTION

110000 DEFINITIVE DESIGR

120000 ENGINEERING AND INSPECTION

SUBTOTAL 1 ENGINEERING

324001 8TH STREET SW WATERLINE CO \#6

324002 275-EA BLDG SW LINE REPAIR CO\#7

324003 HDPE PIPE IN EXISTING LINER CO\#3/\#4

$3240044^{\prime \prime}$ SANITARY WATERLINE CO\#2/\#5

WATER LOOP

324006 8" RAW HATER CROSS TIE

SUBTOTAL 324 W-504 FP CONSTRUCTION COSTS

P

SUBTOTAL 3 CONSTRUCTIOH

o) 400000 PROJECT MANAGEMENT

SUBTOTAL 4 PROJECT HANAGEMENT

510000 PROJECT DEFINITION

520000 CONCEPTUAL DESIGN

530000 PROJECT TECHNICAL SUPPORT

SUBTOTAL 5

OTHER PROJECT COSTS

PROJECT TOTAL

ESTIMATE
SU 8 TOTAL
$======$

\section{CONSTRUCTION MANAGEMENT}

$==$

0.00
0.00

$== \pm== \pm=$

145422

242437

0

0

55194

11027

43891

97873

333379

20102

561466

561466

238539

238539

0.00

21.50
21.50
21.50

21. 50

21.50
21.50

21.50
21.50

2370

9436
21042

71676

4321

120715

120715

OTHER
COSTS
$=\approx=$

292106

292106
87000

87000
554802

933908

0.00

0.00

$====2=0$

$1,976,350$

0
PAGE 6 DF 13

DATE 06/05/97 06:14:54

BY KLR/BPL

$\begin{array}{rr}\begin{array}{c}\text { SUB } \\ \text { TOTAL }\end{array}===== & \begin{array}{r}\text { TOTAL } \\ \text { TOTA }\end{array}====== \\ 0 & 145422 \\ 0 & 97015 \\ 0 & 242437 \\ & \\ 11866 & 67060 \\ 2370 & 13397 \\ 9436 & 53327 \\ 21042 & 118915 \\ 71676 & 405055 \\ 4321 & 24423 \\ 120715 & 682181 \\ 120715 & 682181\end{array}$

238539

238539

292100

87000

554802

933908
120,715

120,715

2, 097,065 
FLUOR DANIEL NORTHHEST, INC. HUMATEC HANFORD CORP

JOB NO. W5O4/P2GEOS

FILE MO. W5OLBAA3

HBS DESCRIPTION

WBSu

110000 DEFINITIVE DESIGN

120000 ENGINEERING AND INSPECTION

SUBTOTAL 1 ENGLNEERING

324001 8TH STREET SH HATERLINE CO \#6

324002 275-EA BLDG SW LIME REPAIR CO\#7

324003 HDPE PIPE IN EXISTING LINER CO\#3/\#4

324004 4" SAHITARY WATERLINE CO\#2/\#5.

324005121 "RAW WATER LOOP

324006 8" RAH HATER CROSS TIE

SUBTOTAL 324 H.504 FP CONSTRUCTION COSTS

CONSTRUCTION

400000 PROJECT MANAGEMENT

SUBTOTAL 4 PROJECT MANAGEMENT

510000 PROJECT DEFINITION

520000 CONCEPTUAL DESIGN

530000 PROJECT TECHNICAL SUPPORT

SUBTOTAL 5

OTHER PROJECT COSTS

PROJECT TOTAL
* * IEST - INTERACTIVE ESTIMATING **

TWRS PRIVATIZATION PYASE I RAL AND SAMITARY WATER

CONCEPTUAL ESTIMATE

CONCEPTUAL ESTIMATE
PHMCRO6 - SITE ALLOCATIONS BY WBS
PAGE 7 OF 13

DATE 06/05\%97 $07: 04: 11$

BY KLR/BPL

\begin{tabular}{|c|c|c|c|c|c|c|}
\hline $\begin{array}{c}\text { ESTIMATE } \\
\text { SUB TOTAL } \\
========\end{array}$ & $\begin{array}{c}D Y N \\
E Q . \cup S A G E \\
==========\end{array}$ & $\begin{array}{l}\text { FDH GFS /G\&A } \\
\text { CONST. MGMT } \\
========\end{array}$ & $\begin{array}{l}F O H \text { MPR } \\
F, P . / S \cdot C . \\
=========\end{array}$ & $\begin{array}{c}F D H \text { GFS / G\&A } \\
\text { LABOR } \\
=========\end{array}$ & $\begin{array}{c}\text { FDH MPR / G\&A } \\
\text { MATER IAL } \\
========\end{array}$ & $\begin{array}{l}\text { SITE ALLOC } \\
\text { SU } 8 \text { TOTAL } \\
========\end{array}$ \\
\hline $\begin{array}{r}145422 \\
97015\end{array}$ & $\begin{array}{l}328 \\
242\end{array}$ & $\begin{array}{l}0 \\
0\end{array}$ & $\begin{array}{l}0 \\
0\end{array}$ & $\begin{array}{l}43464 \\
32053\end{array}$ & $\begin{array}{l}0 \\
0\end{array}$ & $\begin{array}{l}43793 \\
32296\end{array}$ \\
\hline 242437 & 571 & 0 & 0 & 75518 & 0 & 76089 \\
\hline $\begin{array}{r}55194 \\
11027 \\
43891 \\
97873 \\
333379 \\
20102\end{array}$ & $\begin{array}{l}0 \\
0 \\
0 \\
0 \\
0 \\
0\end{array}$ & $\begin{array}{r}3920 \\
783 \\
3117 \\
6952 \\
23681 \\
1427\end{array}$ & $\begin{array}{r}4249 \\
849 \\
3379 \\
7536 \\
25670 \\
1547\end{array}$ & $\begin{array}{l}0 \\
0 \\
0 \\
0 \\
0 \\
0\end{array}$ & $\begin{array}{l}0 \\
0 \\
0 \\
0 \\
0 \\
0\end{array}$ & $\begin{array}{r}8170 \\
1632 \\
6497 \\
14488 \\
49352 \\
2975\end{array}$ \\
\hline 561466 & 0 & 39884 & 43232 & 0 & 0 & 83117 \\
\hline 561466 & 0 & 39884 & 43232 & 0 & 0 & 83117 \\
\hline 238539 & 0 & 0 & 0 & 0 & 0 & 0 \\
\hline 238539 & 0 & 0 & 0 & 0 & 0 & 0 \\
\hline $\begin{array}{r}292106 \\
87000 \\
554802\end{array}$ & $\begin{array}{l}0 \\
0 \\
0\end{array}$ & $\begin{array}{l}0 \\
0 \\
0\end{array}$ & $\begin{array}{l}0 \\
0 \\
0\end{array}$ & $\begin{array}{l}0 \\
0 \\
0\end{array}$ & $\begin{array}{l}0 \\
0 \\
0\end{array}$ & ב \\
\hline 933908 & 0 & 0 & 0 & 0 & 0 & 0 \\
\hline
\end{tabular}

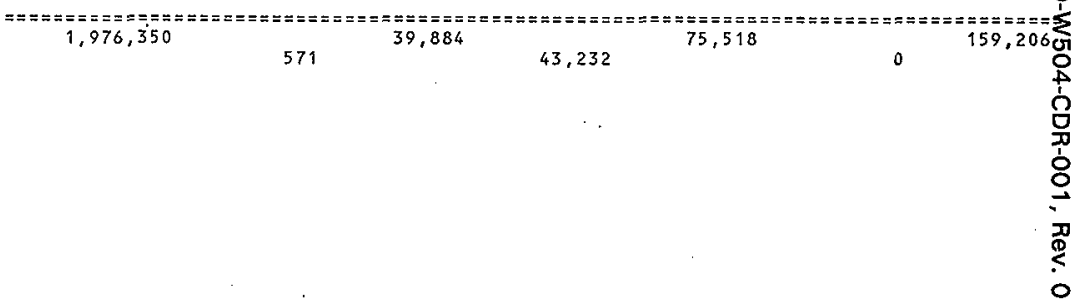


FLUOR DANIEL HORTHWEST, INC.

NUMATEC HANFORD CORP

JOB NO. W5O4/P2GEO

FILE NO. W5O4BAA3

WBS OESCRIPIION

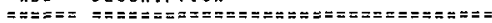

110000 DEFINITIVE DESIGN

120000 ENGINEERING AND INSPECTION

SUBTOTAL 1 ENGINEERING

$3240018 T H$ STREET SW WATERLINE CO \#6

324002 275-EA BLDG SW LINE REPAIR CO\#7

324003 HDPE PIPE IN EXISTING LINER CO\#3/\#4

324004 4" SANITARY WATERLINE CO\#2/\#5

$32400512 "$ RAW WATER LOOP

324006 8" RAH WATER CROSS TIE

SUBIOTAL 324 W.504 FP CONSTRUCTION COSIS

SUBTOTAL 3 CONSTRUCTION

400000 PROJECT MANAGEMENT

SUBTOTAL 4 PROJECT MANAGEMENT

590000 PROJECT DEFINITION

520000 CONCEPTUAL DESIGN

530000 PROJECT TECHNICAL SUPPORT

SUBTOTAL, 5 OTHER PROJECT COSTS

PROJECT TOTAL
* IEST - INTERACTIVE ESTIMATING * *

TWRS PRIVATIZATION PHASE I RAH AND SANITARY WATER CONCEPTUAL ESTIMATE

PHMCROT - SITE ALLOCATION ESCALATION/CONTINGENCY REPORT
PAGE 8 OF 13

DATE 06/05/97 06:15:03

BY $K L R / B P L$

\begin{tabular}{|c|c|c|c|c|c|c|}
\hline $\begin{array}{l}\text { SITE ALLOC } \\
\text { SUBTOTAL } \\
=========\end{array}$ & $==\stackrel{E S C}{\%}=$ & $\begin{array}{l}\text { ALATION } \\
\text { TOTAL } \\
========\end{array}$ & $\begin{array}{c}\text { SUB } \\
\text { TOTAL } \\
===\pi====\end{array}$ & 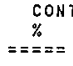 & $\begin{array}{l}\text { INGENCY } \\
\text { TOTAL. } \\
=======\end{array}$ & $\begin{array}{c}\text { TOTAL } \\
\text { DOLLARS } \\
========\end{array}$ \\
\hline $\begin{array}{l}43793 \\
32296\end{array}$ & $\begin{array}{l}4.06 \\
6.08\end{array}$ & $\begin{array}{l}1778 \\
1964\end{array}$ & $\begin{array}{l}45571 \\
34260\end{array}$ & $\begin{array}{l}20 \\
20\end{array}$ & $\begin{array}{l}9114 \\
6852\end{array}$ & $\begin{array}{l}54685 \\
41112\end{array}$ \\
\hline 76089 & 4.92 & $\begin{array}{c}3742 \\
.\end{array}$ & 79832 & 20 & 15966 & 9579 \\
\hline $\begin{array}{r}8170 \\
1632 \\
6497 \\
14488 \\
49352 \\
2975\end{array}$ & $\begin{array}{r}6.17 \\
6.17 \\
6.17 \\
6.17 \\
6.17 \\
6.17\end{array}$ & $\begin{array}{r}504 \\
100 \\
400 \\
893 \\
3045 \\
183\end{array}$ & $\begin{array}{r}8674 \\
1733 \\
6898 \\
15382 \\
52397 \\
3159\end{array}$ & $\begin{array}{l}20 \\
20 \\
20 \\
20 \\
20 \\
20\end{array}$ & $\begin{array}{r}1734 \\
346 \\
1379 \\
3076 \\
10479 \\
631\end{array}$ & $\begin{array}{r}10409 \\
2079 \\
8278 \\
1845 \\
6287 \\
379\end{array}$ \\
\hline 83117 & 6.17 & 5128 & 88245 & 20 & 17649 & 105894 \\
\hline 83117 & 6.17 & 5128 & 88245 & 20 & 17649 & 105894 \\
\hline 0 & 0.00 & 0 & 0 & 0 & 0 & \\
\hline 0 & 0.00 & 0 & 0 & 0 & 0 & \\
\hline $\begin{array}{l}0 \\
0 \\
\quad 0\end{array}$ & $\begin{array}{l}0.00 \\
0.00 \\
0.00\end{array}$ & $\begin{array}{l}0 \\
0 \\
0\end{array}$ & $\begin{array}{l}0 \\
0 \\
0\end{array}$ & $\begin{array}{l}0 \\
0 \\
0\end{array}$ & $\begin{array}{l}0 \\
0 \\
0\end{array}$ & \\
\hline 0 & 0.00 & 0 & 0 & 0 & 0 & \\
\hline
\end{tabular}




\author{
STATEMENT OF WORK \\ FOR \\ PERFORMANCE CONTRACTOR - OTHER PROJECT COSTS \\ SUB-PROJECT W-504 \\ TWRS Privatization Phase I - Raw and Potable Water
}

\title{
I. OBJECTIVE
}

The PHMC performance contractor shall provide project support services to the U. S. Department of Energy, Rich7 and Operations Office (RL) ' from the project's inception through completion of construction and project closeout. In addition to project management/project engineering covered by capital funding ( $F Y 99 \& 2000$ ), other tasks are identified here within the scope of the performance contractor under the heading of Other Project Costs.

The objective of this Statement of Work is to further describe and delineate these tasks for this sub-project.

\section{TASKS}

\section{A. Project Definition}

Principally provides integration of the sub-project with the interfacing organizations established to implement the TWRS Phase I Privatization contract.

a. Systems Integration (FY 96, 97, 98, 99, 00)

1. Support Integrated Product Teams (IPTS) established per the Phase IA contact around KEY M\&I/Privatization Contractor (PC) interfaces.

2. Support the Waste Integration Team (WIT) estab7ished per the Phase IA contract to direct the Phase I effort. Tasks include providing technical information, expertise, etc. necessary in contract negotiations and execution.

3. Maintenance/refinement and updating of Interface Control Documents (ICD), Interface Control Drawings, (ICDwgs), Design Requirement Documents (DRD) based upon IPT negotiations and the reconciliation/closure of. ICD 'issues'.

4. Maintenance/revision of the TWRS Systems Engineering Functional Requirements Database (FRDB) through issuance of change Requests based upon IPT negotiations and the reconciliation of ICD 'issues'. 


\section{B. Conceptual Design}

The Conceptual Design Report for this project has been funded and will be completed in FY 97 . A related Engineering Study and Design Requirements Document were funded and completed in FY 96.

\section{Project Technical Support}

In prior year costs and $F Y 98$, this task includes the project management, project control \& reporting, administrative tasks and activities required to manage the project during the expense funded years prior to actual start of construction and during startup.

Activities include:

- Preparation and update of PBS

- MYWP Planning

- Project Management Plan

- Project reporting and performance monitoring and analysis

- Project Control and Cost/Schedule interfaces

- Establishment and maintenance of Change Control for the Project

- Input and Updates to FM-20 reviews

- Clerical Support as required

- Key Decision and Project Validation support

General Technical Support of activities required by the sub-project for the 7 ife of the project are also included. Due to the tight schedule constraints, this task also includes the preparation of Task Orders, Letters of

Instruction, etc. for definitive design and other related tasks during FY 98 . These other related tasks include:

- Technical leadership, monitoring and reporting

- Preparation of project documentation including Construction Project Data Sheets, Total Project Cost Estimates and Project Schedules

- Establish and maintain project files and provide for records management support for project data

- Prepare Letter of Instruction directing definitive design.

- Provide for Soil Sampling for potential contamination.

- Perform and direct al1 safety, environmental and permitting activities, reviews and technical issues related to the sub-project.

- Provide Radiation Protection Technician (HPI) support as required by the sub-project.

- Provide for startup activity support

- Provide for turnover of project to operating organization

- Provide for official project closeout activities

Specific Technical Support for activities directed by the Project Engineer include:

- Engineering Assessments due to Privatization contract changes

- Water Systems Engineering/Reviews

- Environmental Reviews

- Infrastructure Design Review Support 
- USQ and other safety related support

- Department of Health approval - Potable Water

- Operations reviews and support as required

- ATP, OTP, ORR support as required

- Qualjty Assurance Planning and Implementation

- Safety Planning and Implementation

- Utilities Authorization Basis Review/Modification

Miscellaneous support includes multi-media/duplicating resources, supplies, computer software requirements and desktop support, travel and training as required by the sub-project. 


\section{ENGINEERING STATEMENT OF WORK}

PROJECT NO./TITLE : W-504, Raw and Potable Water

WORK ORDER : E23391

LE $\quad$ : Kirt D. Bare (Civit)

PLE $\quad \vdots$ David L. Fort

PE $\quad$ : Brian C. Harmon

PROJECT SCOPE:

Subproject $W-504$ is one of four projects that make up the TWRS

privatization infrastructure project. This subproject provides the water infrastructure and interfaces necessary to support the demonstration phase (Phase I) of the TWRS privatization.

Subproject $W-504$ will provide the raw and potable water 7 ines to supply the water requirements to the PC sites. Upgrades to the existing potable water system are also included to improve the reliability and flow characteristics to the PC site.

\section{RESPONSIBILITIES:}

Engineering, Design/Orafting and Checking will be performed by individuals from FDNW. The A/I and Construction Management services will be performed by FONW.

\section{REFERENCES:}

1. Conceptual Design Report, TWRS Privatization Phase I Raw and

2. Interface Control Document for Raw Water. WHC-SD-WM-ICD-034. Rev. 0.

3. Interface Control Document for Potable Water, WHC-SD-WM-ICD-035. Rev. 0.

4. Engineering Study, TWRS Privatization Phase I Raw and Potable Water Service, WHC-SD-TWR-ES-002, Rev. 0.

5. Design Requirements Document for TWRS Privatization Phase I, Raw and Potable Water Supply Systems, WHC-SD-WM-DRD-015, Rev. 0.

6. Letter Report. Tank Waste Remediation System Privatization Phase I Water Balance Analysis, E23385LR, dated 9/30/96, by T. Ambalam.

\section{DELIVERABLES:}

1. Civil Drawings (11 each).

2. Construction Specification: W-504-C1. 


\section{CRITERIA DOCUMENTS:}

1. Design Requirements Document for TWRS Privatization Phase I, Raw and Potable Water Supply Systems, WHC-SD-WM-DRD-015. Rev. 0.

2. DOE 6430.1A - General Design Criteria.

\section{ASSUMPTIONS:}

1. The design will satisfy the General Services design requirements.

2. Adequate flow and pressure are available to meet the design requirements for raw and potable water supply. It is not anticipated that a flow analysis will be required.

3. No contaminated soils are anticipated.

4. The existing $16^{\prime \prime} \mathrm{CW}$ line is accessible and can be used as proposed for the installation of the DN300 HOPE pipe within it.

5. The raw and potable water lines will be installed as shown on the sketches ES-W504-C01 through ES-W504-C07 and ES-W505-C07 and ESW505-C08.

MILESTONES AND TARGET DATES:

The Definitive Design schedule is as follows:

Definitive Design

Project Complete
Apr 1998-Aug 1998

oct 1999

RESTRAINTS:

1. Survey and Scanning activities need to be accomplished before the definitive design can start. The schedule will be directly impacted upon a timely receipt the survey data. 


\section{APPENDIX D}

Conceptual Project Schedule 


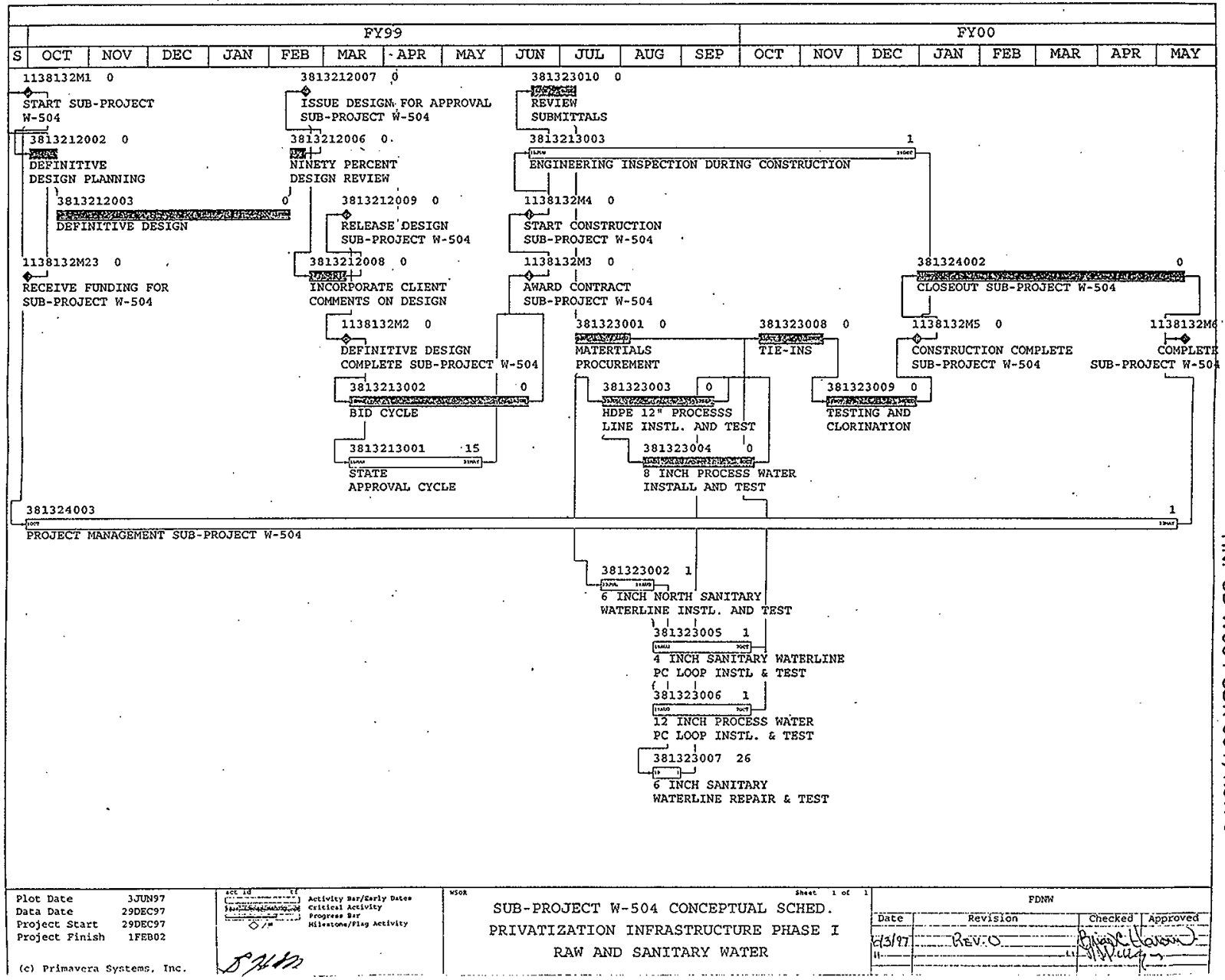




\section{APPENDIX E}

Outine Specification 


\section{OUTLINE SPECIFICATION}

\section{DIVISION 2 - SITEWORK}

\section{Section 02200 Earthwork}

1. Loadbearing backfil1, compacted.

2. Bedding: Sand cushion for pipe, compacted.

3. Control Density Fill: See Section 02237. Material substituted for common and structural backfill and bedding.

4. Plastic sheet marker for buried piping.

5. Soil compaction testing.

Section 02235 Road Subgrade and GranuTar Base

1. Base Course: WSDOT M 41-10

2. Leveling Course: WSDOT M 41-10

\section{Section 02237 Controlled Density Fill}

1. Flowable Concrete Piping Backfill: Design strength 345 to $690 \mathrm{kPa}$ (50 to $100 \mathrm{psi}$ ).

\section{Section 02380 Caissons}

1. Caisson: Bolted galvanized cold-formed steel corrugated multi-plate liner, $2.4 \mathrm{~m}(9 \mathrm{ft})$ diameter, $6 \mathrm{~mm}(1 / 4 \mathrm{in.})$ minimum thickness.

2. Pressure Grout: 1 part cement, 3 part sand.

3. Ladder: Galvanized steel for egress.

Section 02512 Hot-Laid Asphaltic Concrete Pavement

1. Asphalt concrete pavement for pavement repairs, WSDOT M 41-10.

a. Asphalt: AR-4000-W.

b. Aggregate: Class $A$ or $B$, and $G$

\section{Section 02650 Piped Utilities}

1. Potable Water Piping:

a. PVC: AWWA C900, Class 150 . 
b. Ductile Iron, Cement Lined: AWWA C151 and C104, Class 50, with C111 joints.

c. HDPE: AWWA C906, PE 3408.

2. Fittings: Ductile iron; PVC; or

a. PVC: Ductile iron, AWWA C110/C111, lined.

b. Ductile Iron: AWWA C110/C111, lined.

c. HDPE: HDPE extruded elbows.

3. Valves: Cast iron body, resilient seat, gate type, AWWA C500 and C509, flanged, non-rising stem, with indicator post flange.

4. Indicator Post: Adjustable, telescoping-barrel type with locking handle.

5. Corporation Stop: Plug or ball valves, AWWA $C 800$.

6. Encasement Pipe: $200 \mathrm{~mm}$ ( 8 in.), nestable steel culvert pipe conforming to WSDOT M 41-10, Section 9-05.4(8).

7. Manhole: $1.2 \mathrm{~m}(4 \mathrm{ft})$ diameter, precast concrete conforming to WSDOT M 41-10, Section 9-12,4, with open free-draining base. MH ring and cover in accordance with WSDOT M 21-01, Standard Plan B25.

8. Flushing and hydrostatic testing.

9. Disinfected: AWWA C651.

10. Thrust restrained: In accordance with NFPA 24.

\section{Section 02668 Fire Water Systems}

1. Raw/Fire Water Piping: PVC meeting AWWA C900, Class 150; HDPE meeting AWWA C906, PE 3408; or ductile iron, AWWA C151 with C111 joints.

2. Fittings: Ductile iron, AWWA C110/C111, lined; PVC; or HDPE.

3. Valves: Cast iron body, resilient seat, gate, AWWA C500 and C509, flanged, non-rising stem, with indicator post flange.

4. Indicator Post: Adjustable, telescoping-barrel type with locking handle.

5. Fire Hydrants: $150 \mathrm{~mm}$ (6 in.), AWWA C502, dry barre1.

6. Encasement Pipe: $400 \mathrm{~mm}$ (16 in), nestable steel culvert pipe conforming to WSDOT M 41-10, Section 9-05.4(8). 
7. Manhole: See Section 02650 .

8. Flushed and hydrostatic tested.

9. Installation in accordance with NFPA 24.

10. Thrust Restrained: NFPA 24

DIVISION 3 - CONCRETE

Section 03300 Cast-In-Place Concrete

1. Concrete: $25 \mathrm{MPa}(3000 \mathrm{psi})$ minimum strength at 28 days.

2. Reinforcing Steel Bars: ASTM A 615, deformed, Grade 60. 


\section{APPENDIX F}

\section{Energy Conservation Report and Analysis}

Waived ber DOE Letter No. 96 WDD 154 


\section{APPENDIX G}

\section{Unreviewed Safety Ouestion Evaluation}

\section{Provided by Project Ianford Management Contractorl:}

An Unreviewed Safety Ouestion ScreeninglDetermination has been connleted based on the project Design Regirements vocument and the Engineening Study. it was determined that the projed is bounded by existing safety analyses and is within the cuncent Authorization Basis. Therefore, a Prelimimary Sartety Evaluation is not required: 
HNF-SD-W504-CDR-001, Rev. 0

\section{PROJECT $\mathrm{W}-504$ \\ CONCEPTUAL DESIGN \\ UNREVIEWED SAFETY QUESTION}

An Unreviewed Safety Question (USQ) screening/determination was performed using the Project W-504 Design Requirements Document (reference 1), the W-504 Engineering Study (reference 2), and a raw water balance analysis (reference 3). During performance of the USQ screening/determination, TF-97-0387, it was determined that the design does not place the facility outside of that described in the current Tank Waste Remediation System (TWRS) Authorization Basis; Interim Safety Basis (WHC-SD-WM-ISB-00I, Rev $0-M$ ) and RL approved documentation referenced therein.

The existing raw water system in the 200 East services a multitude of facilities. Many of the Authorization Basis documents applicable to the facilities, serviced by the existing raw water system, use a loss of raw water as an initiating event for an accident. Based on the outcome of the water balance analysis, it was judged that the addition of an extension to the existing raw water supply and subsequent reduction of available raw water resources will not cause a loss of raw water. The water balance analysis also showed that there will be ample supply of raw water for the existing facilities along with the ability to meet the supply required by the Privatization Sites. Since project $W-504$ is tapping into the existing raw water system and has demonstrated (through water balance analysis) that the final system will not invalidate existing safety analyses, the project does not impact the current Authorization Basis. No further evaluation needs to be performed at this time per the outcome of the Unreviewed Safety Question screening/determination.

Prior to actual facility modification, the USQ screening/determination will need to be revisited and potentially revised. The reason for revisiting the USQ screening/determination is to ensure that the assumptions remain valid for any new Authorization Basis documentation that might exist at time of construction. Additional USQs might be required depending on Safety Analysis outcome for the Privatization Facilities. Subsequently, updates of Authorization Basis documentation may be required to assure accuracy of facility descriptions.

References: (1) WHC-SD-WM-DRD-015, Rev. 0, Design Requirements Document for TWRS Privatization Phase I Raw and Potable Water Supply Systems, September 30, 1996

(2) WHC-SD-TWR-ES-002, Rev, 0, TWRS Privatization Phase I Raw and Potable Water Service Engineering Study, September 27, 1996

(3) Work Order E23385, Tank Waste Remediation System Privatization Phase I Water Balance Analysis, September 30,1996 
HNF-SD-W504-CDR-00i, Rev. 0

\section{UNREVIEWED SAFETY QUESTION SCREENING/DETERMINATION FORM}

(Per WHC-IP-0842)

Page 1 of 9

USQ Tracking No.

TF-97-0387

Rev. 0

$\begin{array}{llll}\text { AREA: } & {[X] \text { East [] West }[] \text { General }} \\ \text { Facility: } & {[X] 242-A} & {[X] \text { DST }} & \text { [X] SST } \\ & {[X] \text { Aging Waste }} & {[X] \text { Other Project 504 LERF }}\end{array}$

ECN No.

PCA No.

Work Pkg No.

Other (Specify) Project W-504

TITLE: NEW RAW WATER AND POTABLE WATER SYSTEMS FOR TWRS PRIVATIZATION PHASE I

Description of the Proposed Activity/REPORTABLE OCCURRENCE or, PIAB:

Project $W-504$ is in place to provide new raw and potable water systems to the TWRS privatization sites. The proposed activity consists of adding piping to the existing TWRS water supply system and thereby tapping into existing resources. This activity will affect the amount of water available to existing systems and therefore needs to be evaluated.

Introduction:

In pursuing Hanford Site-cleanup efforts, the U.S. Department of Energy (DOE) has decided to privatize the treatment and disposal of radioactive hazardous waste that is contained in Hanford's underground storage tanks. In the privatization effort, vendors, wil1 design; permit, construct, operate, and deactivate their own equipment and facilities. The privatization activities have been divided into two phases. Phase I will demonstrate the effectiveness of the privatization via treatment of a small portion of Hanford's mixed waste $(<13 \%)$. Once demonstrated, the rest of the waste will be treated and disposed of during Phase II.

As part of the privatization contract, DOE has committed to provide utilities to the privatization sites. Project W-504 is in place to provide raw and potable water to the Tank Waste Remediation System (TWRS) privatization sites. The TWRS privatization raw water/fire suppression system will be a looped piping system. The raw water piping system will tie into the existing 200 East raw water and fire suppression system at a location southeast of the 242-A Evaporator. The existing TWRS potable water system will be tapped into near the 207-A basins, to provide potable water to the privatization sites. The potable water line will utilize the same trench as the new raw water line.

Since the project is tieing into the existing 200 East water supply systems, it is evident that there will be an impact in the amount of water availabie. From the project's Design Requirements Document, WHC-SD-WM-DRD-015, it was stated that the raw water distribution system will be able to provide an averaged demand of $290 \mathrm{gpm} 24$ hours a day. Additionally, fire suppression requires a minimum of $2500 \mathrm{gpm}$ to be supplied to both privatization sites at a77 times. The fire suppression system is required to be a continuous supply to both sites at a minimum pressure of 50 psi for a minimum duration of 4 hours. Potable water is required to be supplied to both sites at a demand of $65 \mathrm{gpm}$ for 24 hours a day. 
HNF-SD-W504-CDR-001, Rev. 0

\section{UNREVIEWED SAFETY QUESTION SCREENING/DETERMINATION FORM \\ (Continued)}

Page 2 of 9

USQ Tracking No.

TF-97-0387

Rev. 0

Scope:

This USQ screening/determination evaluates whether project $W-504$, as a system installed, is within the Authorization Basis. Additional USQS will be required once construction begins to determine the short term impact of shutting down systems for tie-in. Since exact specifics are not known at this time, this USQ screening/determination only gives a general overview of the projects ability to reside within the Authorization Basis.

Authorization Basis:

DESH, 1996a, Aging Waste Facility Interim Operational Safety Requirements, WHC-SD-WM-0SR-004, Rev. 1-E, Duke Engineering and Services Hanford, Richland, Washington

DESH, 1996b, Double She77.Tank Interim Operational Safety Requirements, WHC-SD-WM-OSR-016, Rev O-E, Duke Engineering and Services Hanford, Richland, Washington

DESH, 1996c, Single Shell Tank Interim Operational Safety Requirements, WHC-SD-WM-0SR-005, Rev 0-F, Duke Engineering and Services Hanford, Richland, Washington

DESH, 1997a, East and West Tank Farms Standing Order 97-01 - Compensatory Actions For Open Discovery Unreviewed Safety Questions (USQS), Duke Engineering and Services Hanford, Richland, Washington

DESH, 1997b, Hanford Site Tank Farms Facilities Interim Safety Basis, WHC-SDWM-ISB-001, Rev. 0-M, Chapter 6, Duke Engineering and Services Hanford, Richland, Washington

DESH, 1997C, 242-A Evaporator/Crystallizer Safety Analysis Report, WHC-SD-WM- SAR-023, Rev. 2-B, Westinghouse Hanford Company, Richland, Washington

RH0, 1985, 244-AR Vault Safety Analysis Report, SD-WM-SAR-018, Rev 0, Rockwell Hanford Operations, Richland, Washington

RH0, 1986a, Double-Shell Tank Farm Facility (241-AN, AW, AP, and SY) Safety Ana7ysis Report, SD-WM-SAR-016, Rev 1, Rockwell Hanford Operations, Richland, Washington

RH0, 1986b, Single-She77 Tank I solation Safety Analysis Report, SD-WM-SAR-006, Rev 2, Rockwe 11 Hanford Operations, Richland, Washington

WHC, 1989, Aging Waste Facility Safety Analysis Report, SD-HS-SAR-010, Rev 2, Westinghouse Hanford Company, Richland, Washington 
HNF-SD-W504-CDR-001, Rev. 0

UNREVIEWED SAFETY QUESTION SCREENINGIDETERMINATION FORM (Continued)
Page 3 of 9

USO Tracking No.

TF-97-0387

Rev. 0

WHC, 1991, Safety Ana7ysis Report for the 204-AR Waste Unloading Faci7ity, WHC-SD-WMSAR-40, Rev 1, Westinghouse Hanford Company, Richland, Washington

WHC, 1994a, Final Safety Analysis Report: 242-A Evaporator Liquid Effluent Retention Facility, WHC-SD-W105-SAR-001, Rev. 0-D, Westinghouse Hanford Company, Richland, Washington

WHC, I994b, Safety Analysis Report - Stabilization of Single-Shel7 Waste Storage Tanks by Sa7t We77 Jet Pumping, SD-WM-SAR-034, Rev 0-A, Westinghouse Hanford Company, Richland, Washington

WHC, 1996a, Tank Farm Interim Operational Safety Requirements Compliance Implementation.Plan, WHC-IP-0954, Rev 4, Westinghouse Hanford Company, Richland, Washington

Conclusion:

It has been concluded that the proposed activity of a new looped raw water system tied into the existing water supply system is within the Authorization Basis. Further USQS will need to be developed once work packages are created to encompass construction activities.

References

HHC, 1996c, Design Requirements Document for TWRS Privatization Phase I Raw and Potable Water Supply Systems, WHC-SD-WM-DRD-015, Rev. 0, Westinghouse Hanford Company, Richland Washington

FDNW, 1996, Tank Waste Remediation System Privatization Phase I Water Balance Analysis", Work Order E23385, September 30, 1996

USO Screening:

A. Does the PROPOSED ACTIVITY represent a change to the facility as described in the AUTHORIZATION BASIS?

[] No [X] Yes [] N/A

Basis:

Several of the Authorization Basis documents, referenced above (WHC 1989), mention water supply systems and the uses of water within TWRS facilities. The exact specifics including amount of water required and piping locations/layouts are not mentioned. There are accident scenarios written within the Authorization Bases that use loss of water as an initiating event. DOE Order 5480.21 requires "safety evaluations for changes to a nuclear facility that alter the design, function, or method of performing the function of a structure, system, or component (SSC) 
HNF-SD-W504-CDR-001, Rev. 0

UNAEVIEWED SAFETY QUESTION SCREENING/DETERMINATION FORM

(Continued)

Page 4 of 9

USQ Tracking No.

TF-97-0387

Rev. 0

described in the safety analyses either by text, drawing, or other information relied upon as the authorization basis". Since the raw water system is an SSC and the system design is being altered, the proposed activity involves a change to the facility as described in the Authorization Basis.

B. Does the PROPOSED ACTIVITY represent a change to procedures as described in the AUTHORIZATION BASIS?

[X] No [] Yes [] N/A

Basis:

The proposed activity does not represent a change to procedures as described in the Authorization Basis. No existing procedures will be modified as a result of the proposed activity.

C. Does the test or experiment represent a test or experiment not described in the AUTHORIZATION BASIS documentation? .
[X] No
[] Yes
[] $N / A$

Basis:

The proposed activity involves the expansion of the existing raw water and potable water supply systems. No tests or experiments are involved.

D. Does the PROPOSED ACTIVITY or REPORTABLE OCCURRENCE, impact:

- OSRS or lOSRs?

- Approved IOSR Compliance Implementation Plan?

[X] No [] Yes [] N/A

Basis:

There are no OSRs impacted that involve raw water systems. There is an unimplemented IOSR, LCO 3.7.2 (DESH 1996a), that requires Raw Water (RW) and Emergency Cooling Water (ECW) systems to be OPERABLE. Project W-504 wij] not affect the Operability of the raw water system per. the Computer Analysis (FDNW 1996). The privatization requirement of $290 \mathrm{gpm}$ will lessen the amount available to other systems, but the IOSR does not specify how much is required. Fire suppression requirements of $2500 \mathrm{gpm}$ at $50 \mathrm{psi}$ for 4 hours has also been shown by computer analysis (FDNW 1996) to not prevent Operability. A failure of the cooling water support system requires that the Emergency Cooling. Water system be used, which is a separate system and will remain non-impacted by the project. Since the project will not affect the Operability of the raw water system and will not affect the Emergency Cooling water system, the proposed activity does not impact LCO 3.7.2. 
HNF-SD-W504-CDR-001, Rev. 0

UNREVIEWED SAFETY QUESTION SCREENING/DETERMINATION FORM

(Continued)

Page 5 of 9

USQ Tracking No.

TF-97-0387

Rev. 0

E. Does the REPORTABLE OCCURRENCE or PIAB involve analytical errors, omissions, and/or deficiencies in the AUTHORIZATION BASIS?

[] No [] Yes [X] N/A

Basis:

The proposed activity does not involve a PIAB or Reportable Occurrence.

USOE No. 1 Matthew.S. Tiffany

Print Name.

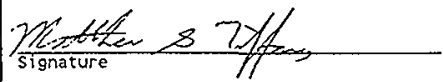

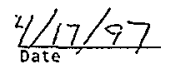

USQE No. 2 Daniel J. Minteer Print Name

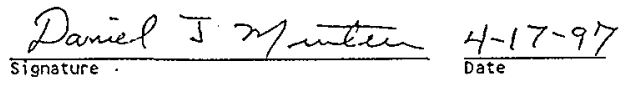

IF "YES", USQE CONTINUE WंITH DETERMINATION BELOW

USQ DETERMINATION:

1. Could the PROPOSED ACTIVITY, REPORTABLE OCCURRENCE or PIAB significantly increase the frequency of occurrence of an accident previously evaluated in the AUTHORIZATION BASIS?

[X] No [] Yes/Maybe

Basis:

An event from table 9-4 (WHC 1989) involves the Condensers in a loss of cooling water. The sequence involving a raw water failure results in steam not condensing and surface condensers heating up. This results in thermal stress rupturing the condenser and contaminated cooling water being released to the pond. The preventive features of this accident rely on low water pressure alarms at a pressure of $<30$ psig, metal mass of condenser preventing rapid heat up, and the condenser being designed for temperatures of $212^{\circ} \mathrm{F}$. The proposed activity does not impact or alter any of the preventive features of the accident. The mitigating measures state that thermocouples and pressure sensing instruments are set to alarm before damage occurs. An additional mitigating measure relies on the emergency cooling water being supplied from either spare pumps or from well pumps: The proposed activity does not involve the Emergency cooling Water system and will not impact the thermocouples or pressure sensing instruments of the condensers. There is no mention of the amount of cooling water required for the condensers other than the low pressure alarm set point of $30 \mathrm{psig.} \mathrm{The} \mathrm{proposed} \mathrm{activity} \mathrm{has} \mathrm{been} \mathrm{evaluated}$ via computer model (FDNW 1996) to show the available pressure of the system at 2500 gpm. From the results, an engineering judgement can be concluded that the pressures (detemined to be $>90 \mathrm{psi}$ ) will remain sufficient to not cause a loss of raw water. The loss of raw water is only an event and not an accident in itself. The $A B$ document (WHC 1989) states that the hazards identified were compared to each other, 
HNF-SD-W504-CDR-001; Rev. 0

UNREVIEWED SAFETY QUESTION SCREENING/DETERMINATION FORM

(Continued)
Page 6 of 9

USO Tracking No.

TF-97-0387

Rev. 0

on the basis of source terms and consequences, to determine the accidents. With the preventive features and mitigating measures in place and not altered by the proposed activity, the proposed activity will not increase the frequency of occurrence of an accident evaluated in SAR-10 WHC 1989.

An accident involving the raw water system is described in table 4-8 (WHC 1991). The cause of the accident is a line failure resulting in a loss of water to safety showers and pump seals, and fire protection. In the Mitigating/Preventive features column of the table, it is stated that the fire protection system can be pressurized with a tanker truck. From the computer analysis, an engineering judgement can be made that the raw water system will have sufficient pressures after the proposed activity. Additionally, the Mitigating/Preventive features are not being altered by the proposed activity. Therefore, the proposed activity does not increase the frequency of occurrence of the raw water accident described in WHC 1991.

Table 9-3 of SAR-018 (RHO 1985) contains an event dealing with cooling water. The event assumes a breakage or shut down of the raw water transport line. As demonstrated above, the frequency of a loss of cooling water is not increased as a result of the proposed activity. Even with a loss of cooling water, the 244-AR facility is in a shutdown mode and is set for deactivation. The consequences of the cooling water accident include loss of control room instrumentation and a loss of control of the vessel ventilation system diaphragm valves due to a loss of cooling to the compressor. The compressor that the SAR is describing is no longer in service for ecological reasons and additionally the vessel ventilation system is no longer in service. There is a closed loop cooling system which provides the instrument air with a portable air compressor used as a backup. Therefore, the proposed activity does not increase the frequency of occurrence of an accident described in RHO 1985.

The Evaporator SAR (DESH 1997C) evaluated the hazard of a loss of raw water supply and pressure in table 9-4. The accident and potential consequences are 1) a loss of desuperheater and overheating of evaporator contents resulting in a flashover into the condenser and 2) loss of pump seals leading to a potential evaporator overflow. The mitigating measures rely on interlocks and alarm response features to prevent. the accident from occurring. Since the proposed activity is not altering the interlocks or alarm response procedures, the proposed activity will not increase the frequency of occurrence of the accidents.

In summary, the proposed activity of providing water to the privatization sites has been judged to not cause a failure of the raw water system. A raw water loss was the only event analyzed for the raw water system. Additionally, the preventive features and mitigating measures are not being altered by the proposed activity. Therefore, the proposed activity will not increase the frequency of an accident previously analyzed in the Authorization Basis. 
Rev. 0

2. Could the PROPOSED ACTIVITY, REPORTABLE OCCURRENCE or PIAB significantly increase the consequences of an accident previously evaluated in the AUTHORIZATION BASIS?

[X] No [] Yes/Maybe

Basis:

As demonstrated in question 1 , the only accidents involving the raw water system involve a loss of raw water for cooling purposes and fire suppression. It has been elaborated that the proposed activity of providing raw and potable water to the privatization sites will not result in a loss of water. As stated in the scope section, the proposed activity is limited to a general overview of the project and does not take into account construction activities, which will be evaluated later. Since the proposed activity will not increase the frequency of an accident and does not add any source term to the system, the proposed activity will not increase the consequences of an accident previously analyzed in the Authorization Basis.

3. Could the PROPOSED ACTIVITY, REPORTABLE OCCURRENCE or PIAB significantly increase the frequency of occurrence of a malfunction of EQUIPMENT IMPORTANT TO SAFETY previously evaluated in the AUTHORIZATION BASIS?

[X] No [] Yes/Maybe

Basis:

The only equipment important to safety involved with the proposed activity is the raw water system. It has been demonstrated through computer analysis (FDNW 1996) that the existing system is capable of handling the extra demand that the privatization sites require. Therefore, based on the calculation, it is an engineering judgement that the proposed activity will not significantly increase the frequency of occurrence of a malfunction of the raw water piping system.

4. Could the PROPOSED ACTIVITY, REPORTABLE OCCURRENCE or PIAB significantly increase the consequences of a malfunction of EQUIPMENT IMPORTANT TO SAFETY previously evaluated in the AUTHORIZATION BASIS?

[X] No [] Yes/Maybe

Basis:

As demonstrated in question 3 , the only equipment important to safety which is affected is the raw water system. The consequences of a malfunction of the raw water system will remain the same as a result of the proposed activity. Similarly, since the frequency is not increased and no source term is being added to the system by the proposed activity, the proposed activity will not increase the consequences of a malfunction of the raw water system. 
HNF-SD-W504-CDR-001, Rev. 0

UNREVIEWED SAFETY QUESTION SCREENINGIDETERMINATION FORM

(Continued)

Page 8 of 9

USO Tracking No.

TF-97.-0387

Rev. 0

5. Could the PROPOSED ACTIVITY, REPORTABLE OCCURRENCE or PIAB create the possibility of an accident of a different type than any previously evaluated in the AUTHORIZATION BASIS?

[X] No [] Yes/Maybe

Basis:

The only accident involving raw water is a loss of raw water supply leading to a loss of cooling water or fire suppression. No other accident scenarios are credible. Therefore, the proposed activity does not create the possibility of an accident other than that previously evaluated in the Authorization Basis.

6. Could the PROPOSED ACTIVITY, REPORTABLE OCCURRENCE or PIAB create the possibility of a malfunction of EQUIPMENT IMPORTANT TO SAFETY of a different type than any previously evaluated in the AUTHORIZATION BASIS?

[X] No [] Yes/Maybe

Basis:

The only equipment important to safety that is involved with the proposed activity is the raw water system. No other equipment important to safety can be identified as it relates to the proposed activity. Therefore, the proposed activity can not create the possibility of a malfunction of equipment important to safety of a different type than previously evaluated in the Authorization Basis.

7. Could the PROPOSED ACTIVITY, REPORTABLE OCCURRENCE Or PIAB reduce the margin of safety for any OSR/IOSR as defined in the AUTHORIZATION BASIS?

[X] No [] Yes/Maybe

Basis:

There are no OSRS or Implemented IOSRs which rely on the raw water system. A failure of the raw water system will not occur as a result of the proposed-activity. Additionally, the system will not introduce new system interactions on the raw water system which could result in the reduction of the margin of safety (i.e. increase of pressure above the design limits of the existing system). Therefore, the proposed activity will not reduce the margin of safety for any OSR/IOSR as defined in the Authorization Basis. 
HNF-SD-W504-CDR-001, Rev. 0

\section{UNREVIEWED SAFETY QUESTION SCREENING/DETERMINATION FORM (Continued)}

Page 9 of 9

USQ Tracking No. TF-97-0387

Rev. 0

8. Does the PROPOSED ACTIVITY, REPORTABLE OCCURRENCE or PIAB require a new or revised OSR/IOSR (including compensatory measures required by a Compliance Implementation Plan)?

[X] No [] Yes/Maybe

Basis:

No revised OSR/IOSR is required at this time since no OSRs exist and the only IOSR (unimplemented) is not impacted by the proposed activity. Once more details are developed regarding the raw water safety requirements, if any, that the privatization facilities may have, additional USQS may be required. The future USQs might require new OSRs based upon future safety analysis outcome. At this time, however, this USQ can only provide a general overview of the project as it impacts the existing system and does not require new OSRs.

USOE No. 1 Matthew S. Tiffany

$$
\text { print Name }
$$

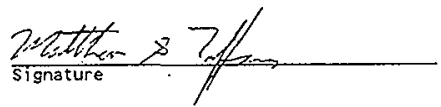

Meeting No.:

PRC Chairman Concurrence:
USOE No. 2 Daniel J. Minteer.
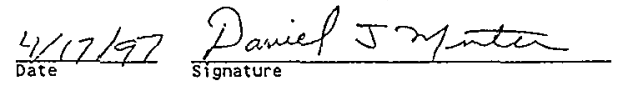
$\frac{4-17-97}{\text { Date }}$

\section{PRC REVIEW}

Date 


\section{APPENDIX $H$}

Economic Analysis and Life Cycle Cost Aralysis Waived per DOE (Eetter No. 96-WDB 154 I 


\section{APPENBIX}

Physically Handicapped Assessment

Waived per DoE Letter. No. 96-WDDD 1541 
HNF-SD-W504-CDR-001, Rev. 0

\section{APPENDIX J}

Plant Forces Work Review 


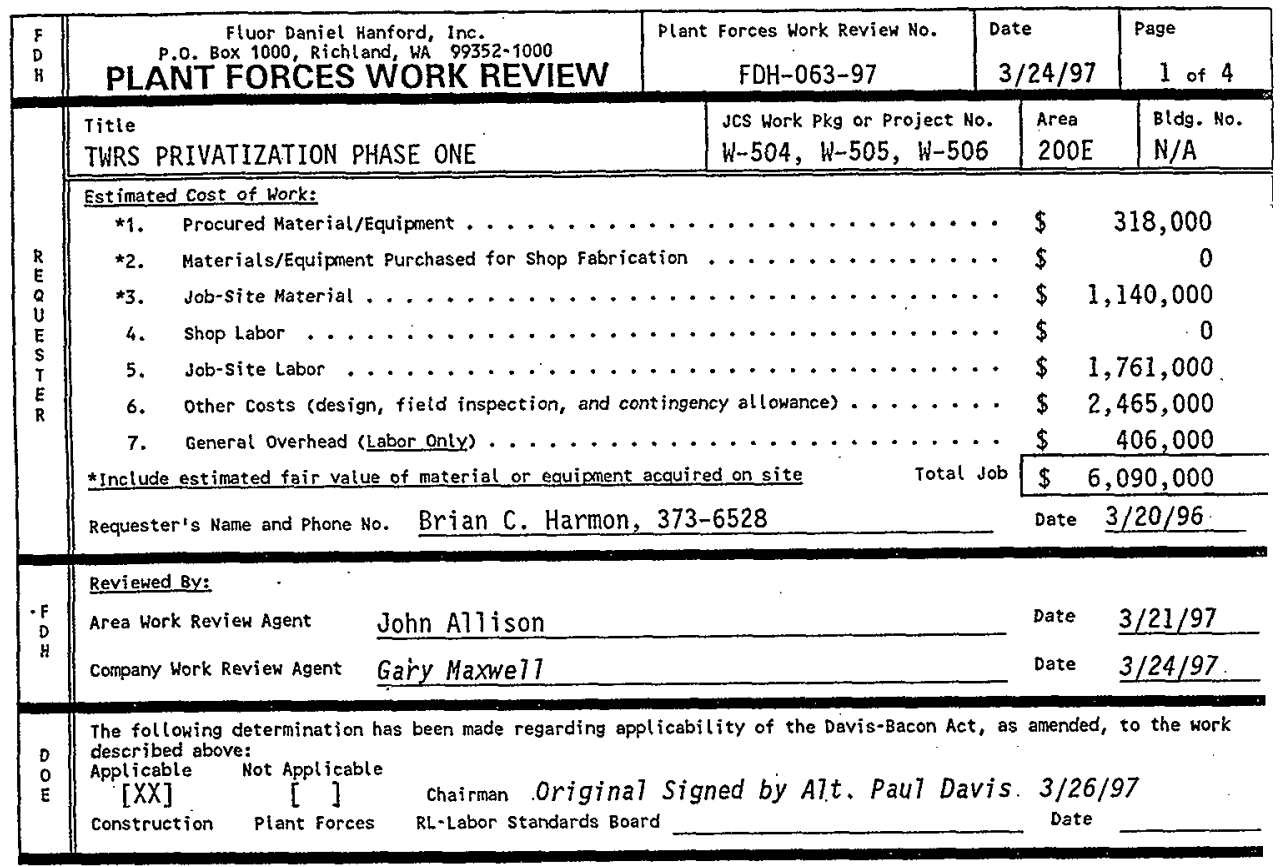

"Description of Work"

Briefly state the reason for this work activity:

In collaboration with numerous parties, the U.S. Department of Energy (DOE) has decided to privatize the treatment and disposal of most of the radioactive hazardous waste contained in the underground storage tanks on the Hanford site. In order to provide infrastructure to the new privatization site, a new 230 KV Substation, Raw and Sanitary water distribution systems, Site Development and Roads, and Liquid Effluent Systems must be extended from the existing Hanford infrastructure.

Project $(-1-504)$ is one of the four projects that will provide site development and infrastructure to the Privatization Site. All four conceptual design efforts are currently underway. This PFWR combines scope for three of the four projects. W-503 (FDH-053-97 attached) was submitted for a determination without the CWRAs knowledge of Projects $W-504,505$, and 506. The other three projects are listed below:

W-504 -.... TWRS Privatization Phase I, RaW and Sanitary Water Service

W-505 -....- TWRS Privatization Phase I, Site Development and Roads

W-506 -...-- TWRS Privatization Phase I, Liquid Effluent Systems

Job sumary:

W-504 Grub, grade, insta 71 approximately 7,200 ' of 4" \& 6" sanitary water 7 ine, $11,200^{\prime}$ of $12^{\prime \prime}$ raw water line and appropriate valves. 
HNF-SD-W504-CDR-001, Rev. 0

\begin{tabular}{|c|c|c|c|}
\hline $\begin{array}{l}F \\
D \\
H\end{array}$ & 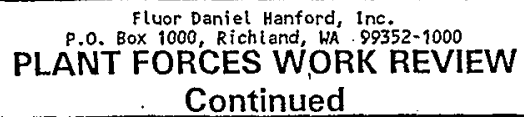 & $\begin{array}{l}\text { Plant Forces Work Reviek No. } \\
\text { FDH-063-97 }\end{array}$ & $\begin{array}{l}\text { Page } \\
2 \text { of } 4\end{array}$ \\
\hline
\end{tabular}

W-505 Grub, grade, insta17 approximately 5,800' of new paved roadways, 5, 200' of upgrades to existing roadway, and $3,000^{\prime}$ of new power 7 ines.

W-506 Grub, grade, insta $77,500^{\prime}$ of $2^{\prime \prime} \& 6^{\prime \prime}$ effluent piping. 4,000' of excavation $x$ $3^{\prime}$ to $10^{\prime}$ deep is required.

Discuss all programatic or physically associated work planned, underway, or recently completed in the work area:

FDH-053-97 is directiy associated with the aforementioned projects.

Describe entire work scope. Fully describe complete job scope using a stepped work flow format. Describe and estimate the cost of labor and material on foundations, structures, utility systems, or other construction type activity. Provide sketches or measurements for all work:

W-504:

Estimated Cost of Work:

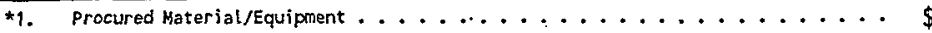

*2. Materials/Equipnent purchased for shop fabrication ............. \$

*3. Job-site Material .............................\$

4. shop labor ...........................\$

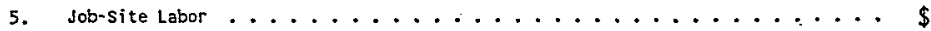

6. Other costs (design, field inspection, and contingency allowance) ...... \$

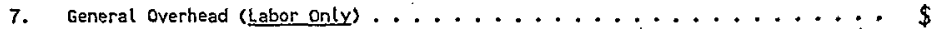

*Include estimated fair value of material or equipment acquired on site

Total Job $\$$

$\$ 1,865,000$

W-504 will extend the existing Hanford Site sanitary and raw water systems to the TWRS Privatization Site. The sanitary water 7 ine will be extended to provide potable water and the raw water iine will be extended to provide untreated process \& fire suppression water to the new site. Both new water lines will be looped for increased reliability.

1. Perform grubbing \& grading activities on the proposed utility corridors. (approximately $25 \mathrm{~K}$ )

2. Install approximately $7,200^{\prime} \times 4^{\prime \prime} \& 6^{\prime \prime}$ sanitary water line. The new 7 ines will be installed between $4^{\prime}$ and $5^{\prime}$ deep. The new lines will be installed with the appropriate valves to meet existing and proposed operational and fire protection requirements. (Approximately 440K)

3. Install approximately 11,200 ! $\times 12^{\prime \prime}$ raw water 7 ine. The new line will be installed between $4^{\prime}$ and $6^{\prime}$ deep. The new 7 ine will be installed with the appropriate valves to meet existing and proposed operational and fire protection requirements. (Approximately 840K)

4. Perform flushing and testing of the new water lines. (Approximately 25K)

5. Perform soil stabilization. (Approximately 15K)

Note: All sagebrush mitigation and re-vegetation activities will be performed under Project W-505 (Site Development jand Roads). 


\begin{tabular}{|c|c|c|c|}
\hline Fluor Daniel Hanford, Inc. & $\begin{array}{c}\text { P.o. Box 1000, Richland, WA } 99352-9000 \\
\text { PLANT FORCES WORK REVIEV } \\
\text { Continued }\end{array}$ & FDH-063-97 Forces Work Review No. \\
\hline
\end{tabular}

W-505:

Estimated cost of Work:

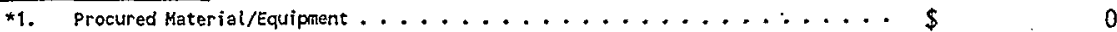

*2. Materials/Equipment.Purchased for shop Fabrication ............ \$

Ł. Job-site Material .......................... \$

430,000

4. Shop Labor ............................. \$

0

5. Job-site tabor . . . . . . . . . . . . . . . \$

620,000

6. Other costs design, field inspection, and contingency allowance) .......

$1,575,000$

7.

*Include estimated fair value of material or equipment acquired on site

....

110,000

II

In order to provide infrastructure to the new privatization site, the site must be cleared and developed with roads, lighting, and temporary construction power.

This effort will develop the TWRS Privatization Site by extending the existing Hanford Site roads and electrical power (temporary construction service only) to the TWRS Privatization Site.

1. Perform grubbing \& grading activities on the TWRS Privatization Phase I Site. (approximately 135K)

2. Install approximately $5 ; 800^{\prime}$ of new paved roadways. (Approximately $395 \mathrm{~K}$ )

3. Insta71 approximately 5,200' of upgrades to existing Hanford Site roadways. (Approximateiy 139K)

4. Install approximately 3,000' of new power lines. Approximately twelve poles witl be removed or relocated and approximately fifteen new poles will be added. The new electrical service will provide security lighting and temporary construction power to the privatization contractors. (Approximately 220K)

5. Perform soil stabilization and re-vegetation activities at the Privatization Site. (Approximately 160,000)

6. Perform sagebrush mitigation per DOE-RL requirements. Approximately 95 acres of sagebrush habitat will be cleared as a part of TWRS Privatization Phase I. (Approximately 1,300K) 


\begin{tabular}{|c|c|c|c|}
\hline $\begin{array}{l}F \\
D \\
\text { H }\end{array}$ & $\begin{array}{c}\text { Fluor Daniel Hanf ord, lne. } \\
\text { P.o. Box } 1000, \text { Richland, WA } 99352-1000 \\
\text { CoNT FORCES WORK REVIEW } \\
\text { Continued }\end{array}$ & $\begin{array}{l}\text { Plant Forces Hork Revien No. } \\
\qquad \text { FDH }-063-97\end{array}$ & $\begin{array}{l}\text { Page } \\
4 \text { of } 4\end{array}$ \\
\hline
\end{tabular}

W-506:

\begin{tabular}{|c|c|c|c|}
\hline *1. & Procured Material/Equipment $\ldots \ldots \ldots \ldots \ldots$ & $\$$ & 318,000 \\
\hline *2. & Materials/Equipment Purchased for Shop fabrication $\ldots \ldots \ldots$ & $\$$ & 0 \\
\hline *3. & Job-site Material $\ldots \ldots \ldots \ldots \ldots \ldots \ldots \ldots$ & $\$$ & 135,000 \\
\hline 4. & $\ldots \ldots \ldots \ldots \ldots \ldots \ldots \ldots$ & $\$$ & 0 . \\
\hline 5. & Job-site Labor $\ldots \ldots \ldots \ldots \ldots \ldots \ldots$ & $\$$ & 371,000 \\
\hline 6. & Other costs (design, field inspection, and contingency allowance) .... & $\$$ & $5.15,000$ \\
\hline 7. & General Overhead (Labor only) $\ldots \ldots \ldots \ldots \ldots$ & $\$$ & 151,000 \\
\hline xelu & estimated fair value of material or equipment acquired on site & $\$$ & $1,490,000$ \\
\hline
\end{tabular}

In order to accomplish this, a new pipeline system must be installed between the new privatization site and the existing 200 Area liquid effluent facilities. These new pipelines will provide the necessary means of transferring pre-treated liquid effluent from the new privatization contractors.

This effort will install a 7iquid effluent transfer system for the TWRS Privatization Site. The new effluent system will provide a reliable means of transferring radioactive, dangerous liquid effluent and non-radioactive, non-dangerous liquid effluent to the 200 Area liquid effluent facilities. Two separate pipelines must be installed to keep the different waste types from commingling.

1. Perform grubbing \& grading activities on the proposed utility corridors. (Approximately 25K)

2. Install approximately $7,500^{\prime}$ of 1 iquid effluent pipeline with associated drain tanks \& valves. The new pipelines will be sized between $2^{\prime \prime}$ and $6^{\prime \prime}$ in diameter and will be installed between $3^{\prime}$ and $10^{\prime}$ deep. Both pipelines (radioactive, dangerous \& nonradioactive, non-dangerous) will be placed in the same trench for a significant portion of each run. Approximately 4,000 lineal feet of trenching will be required for this work. (Approximately 644K)

3. Install the necessary electronics and monitoring equipment for the new liquid effluent system. Data signals will be transmitted over the Hanford Site telecommunications system. (Approximately 115K)

4. Perform flushing and testing of the new effluent lines. (Approximately 30K)

5. Perform soil stabilization. (Approximately 10K)

Note: All sagebrush mitigation and re-vegetation activities will be performed under Project W-505 (Site Development and Roads). 


\section{APPENDIX K}

Pollution Prevention Waste Minimization 
P2-EDGE SUMMARY REPORT

Project Information

Project:

TWRS Privatization Phase I Raw and Sanitary Water

Tarik Choho

2440 Stevens Place, Roon 1215

Address:

(509) 376-0590

Phone:

Line Item Project

Project size:

Type of Project:

New Construction

Design Phase:

P2-EDGE Analysis

origination date: $\quad 25$ Feb 97

Evaluator Comments

Name: $\quad$ David Fort

Telephone number: $\quad$ (509) 376-4250

Notes

Data is unfiltered.

Opportunities that WILL BE CONSIDERED:

$\begin{array}{lllllllll}1 . A .3 & 1 . A .8 & 1 . A .9 & 1 . A .19 & 1 . A .21 & 1 . A .24 & 1 . B .2 & 1 . B .5 & 1 . B .6 \\ 1 . B .7 & 1 . D .2 & 2 . B .11 & 3 . B .1 & 3.8 .2 & 3 . B .4 & 6 . B .1 & 6 . B .2 & 6.0 .1 \\ 9 . A .5 & 9 . A .6 & 9 . A .7 & 9.8 .1 & 9 . B .2 & 9 . B .3 & 9 . D .1 & 11 . A .1 & 11 . A .10 \\ 11 . B .2 & 15 . A .25 & & & & & & & \end{array}$

Opportunities that WILL NOT BE CONSIDERED:
1.A.20
2.A.3
2.A.8
3.B.3
$5 . A .2$

Opportunities that WILL BE IMPLEMENTEO:

1.A.2 2.A. 10

Opportunities that are NOT APPLICABLE:

\begin{tabular}{|c|c|c|c|c|c|c|c|c|}
\hline $\begin{array}{l}\text { 1.A.1 } \\
1 . A .14 \\
1 . A .27 \\
1 . B .10 \\
2 . A .4 \\
2 . A .15 \\
2 . B .8 \\
3 . A .1 \\
7 . A .1 \\
8 . B .1 \\
9 . A .11 \\
11 . A .3 \\
11 . A .13 \\
11 . A .22 \\
11 . D .1 \\
12 . B .6 \\
13 . A .9 \\
13 . A .18 \\
13 . B .4 \\
15 . A .2 \\
15 . A .11 \\
15 . A .20 \\
15 . B .2 \\
16.3\end{array}$ & $\begin{array}{l}1 . A .4 \\
1 . A .15 \\
1 . A .28 \\
1 . B .11 \\
2 . A .5 \\
2 . A .16 \\
2 . B .9 \\
4 . A .1 \\
7 . A .2 \\
8 . B .2 \\
10 . A .1 \\
11 . A .4 \\
11 . A .14 \\
11 . A .23 \\
12 . A .1 \\
13 . A .1 \\
13 . A .10 \\
13 . A .19 \\
13 . B .5 \\
15 . A .3 \\
15 . A .12 \\
15 . A .21 \\
15 . B .3 \\
16 . A .4\end{array}$ & $\begin{array}{l}1 . A .5 \\
1 . A .16 \\
1 . A .29 \\
1 . B .12 \\
2 . A .6 \\
2 . B .1 \\
2 . B .10 \\
4 . B .1 \\
7 . B .1 \\
9 . A .1 \\
10 . A .2 \\
11 . A .5 \\
11 . A .15 \\
11 . A .24 \\
12 . A .2 \\
13 . A .2 \\
13 . A .11 \\
13 . A .20 \\
13 . C .1 \\
15 . A .4 \\
15 . A .13 \\
15 . A .22 \\
15 . B .4 \\
16 . A .5\end{array}$ & $\begin{array}{l}1 . A .6 \\
1 . A .17 \\
1 . A .30 \\
1 . B .13 \\
2 . A .7 \\
2 . B .2 \\
2 . B .12 \\
4 . B .2 \\
7 . B .2 \\
9 . A .2 \\
10 . A .3 \\
11 . A .6 \\
11 . A .16 \\
11 . A .25 \\
12 . A .3 \\
13 . A .3 \\
13 . A .12 \\
13 . A .21 \\
13 . C .2 \\
15 . A .5 \\
15 . A .14 \\
15 . A .23 \\
15 . B .5 \\
16 . A .6\end{array}$ & $\begin{array}{l}1 . A .7 \\
1 . A .18 \\
1 . B .1 \\
1 . C .1 \\
2 . A .9 \\
2 . B .3 \\
2 . B .13 \\
5 . A .1 \\
7 . B .3 \\
9 . A .3 \\
10 . A .4 \\
11 . A .7 \\
11 . A .17 \\
11 . A .26 \\
12 . B .1 \\
13 . A .4 \\
13 . A .13 \\
13 . A .22 \\
13 . D .1 \\
15 . A .6 \\
15 . A .15 \\
15 . A .24 \\
15 . B .6 \\
16 . A .7\end{array}$ & $\begin{array}{l}1 . A .10 \\
1 . A .22 \\
1 . B .3 \\
1 . D .1 \\
2 . A .11 \\
2 . B .4 \\
2 . C .1 \\
5 . B .1 \\
7 . B .4 \\
9 . A .4 \\
10 . B .1 \\
11 . A .8 \\
11 . A .18 \\
11 . A .27 \\
12 . B .2 \\
13 . A .5 \\
13 . A .14 \\
13 . A .23 \\
13 . D .2 \\
15 . A .7 \\
15 . A .16 \\
15 . A .26 \\
15 . C .1 \\
16 . A .8\end{array}$ & $\begin{array}{l}\text { 1.A.11 } \\
1 . A .23 \\
1 . B .4 \\
1 . D .3 \\
2 . A .12 \\
2 . B .5 \\
2 . C .2 \\
5 . B .2 \\
8 . A .1 \\
9 . A .8 \\
10 . C .1 \\
11 . A .9 \\
11 . A .19 \\
11 . B .1 \\
12 . B .3 \\
13 . A .6 \\
13 . A .15 \\
13 . B .1 \\
13 . D .3 \\
15 . A .8 \\
15 . A .17 \\
15 . A .27 \\
15 . D .1 \\
16 . A .9\end{array}$ & $\begin{array}{l}1 . A .12 \\
1 . A .25 \\
1 . B .8 \\
2 . A .1 \\
2 . A .13 \\
2 . B .6 \\
2 . D .1 \\
5 . C .1 \\
8 . A .2 \\
9 . A .9 \\
10 . D .1 \\
11 . A .11 \\
11 . A .20 \\
11 . B .3 \\
12 . B .4 \\
13 . A .7 \\
13 . A .16 \\
13 . B .2 \\
14 . A .1 \\
15 . A .9 \\
15 . A .18 \\
15 . A .28 \\
16 . A .1 \\
16 . A .10\end{array}$ & $\begin{array}{l}1 . A .13 \\
1 . A .26 \\
1 . B .9 \\
2 . A .2 \\
2 . A .14 \\
2 . B .7 \\
2 . D .2 \\
6 . B .3 \\
8 . A .3 \\
9 . A .10 \\
11 . A .2 \\
11 . A .12 \\
11 . A .21 \\
11 . C .1 \\
12 . B .5 \\
13 . A .8 \\
13 . A .17 \\
13 . B .3 \\
15 . A .1 \\
15 . A .10 \\
15 . A .19 \\
15 . B .1 \\
16 . A .2 \\
16 . A .11\end{array}$ \\
\hline
\end{tabular}


POLLUTION PREVENTION/WASTE MINIMIZATION OPPORTUNITIES DESIGN CHECKLIST

Dated: 5-6-97

PROJECT NUMBER $\mathrm{W}-504$

PROJECT TITLE _ TWRS PRIVATIZATION, PHASE I - RAW AND SANITARY WATER

PROJECT CONTRACTOR NHC

PROJECT MANAGER TARIK CHOHO

DESIGN CONTRACTOR

FDNW

DESIGH AGENT

FDNW

Opportunity Number 1.A.2

Description: 8ell and spigot gasketed pipe will be used in the definitive design.

Nill Consider

il Not Consider Implemented Not Appl icable

Opportunity Number 1.A.3

Will Consider $\mathrm{X}$ Will Not Consider
Implemented Not Appl icable

Description: Design considered minimum route length to meet the project requirements

Opportunity Number 1. A.8

$\mathbf{X}$

Will Consider Will Not Consider Implemented

Description: Definitive design uill require dust mitigation practices. Not Appl icable

Opportunity Number 1.A.9

Will consider Will Not Consider Implemented Not Appl icable Description: Conceptual design evaluated materials and selected a minimum number of appropriate materials to be used during definitive design.

Opportunity Number 1. A.19

Will Consider Will Not Consider Implemented

Description: To be implemented in the construction specification during definitive design. Not Applicable

Opportunity Number 1. A.20

Will Consider $\mathrm{X}-\mathrm{Will}$ Not Consider Implemented Not Applicable Description: Freeze protection is best accomplished with direct burial of the lines. Raw and sanitary water lines do not pose a contamination problem.

Opportuni ty Number 1.A.21

Will Consider Will Not Consider Implemented $\mathrm{X}$

Description: Water line installation does not lend itself to the use of precut or premanufactured materials. Not Applicable

Opportunity Number 1.A.24

WîlL Consider $\begin{array}{r}\text { Will Not Consider } \\ \text { implemented } \\ \hline \text { Not Appl icable }\end{array}$

Description: Definitive design specifications will require minimum material requirements. 
Opportunity Number 1. B.5

Description: To be considered during procurement of equipment and materials. Not Appl icable

Opportunity Number 1.B.6

Will Consider

Will Not Consider

Inpl emented

Description: Water line packaging materials are not reusable.

Not Appl icable

Opportunity Number 1.B.7

$\mathrm{x}$

Will Consider Will Not Consider Impl emented Not Appl icable Description: Will be considered during definitive design and implemented as appropriate in the construction specification/s. Opportunity Number 1.0.2

Will Consider \begin{tabular}{r}
\hline $\mathrm{W}$ \\
\hline Will Not Consider \\
Implemented \\
Not Appl icable
\end{tabular} Description: Construction specifications will require appropriate containnent.

Will Consider Opportunity Number 2.A.3

Not Consider Jmplenented

Description: storm water runoff to bodies of water is not possible at the site. Not Appl icable

Opportunity Number 2.A.8

Will Consider $\mathrm{X}$ Will Not Consider Impl emented Not Appl icable Description: Project site is an arid region. Unless watered, landscaping to reduce stormwater runoff will generatly not survive.

Opportunity Number 2.A.10

Will Consider Will Not Consider 1 mol emented

Description: Definitive design will define percolation areas as applicable. Not Appl icable

Opportunity Number 2.3 .11

Will Consider $\mathrm{X}$ Will Not Consider
Implemented Not Appl icable Description: Water for open bore flushing of the new lines will be too large a quantity in too short a period to be captured for secondary use.

Opportunity Number 3.8 .1

$x$

Will Consider Will Not Consider Implemented Not Appl icable Description: Will be considered during definitive design and implemented as appropriate in the construction specification/s. Opportunity Number 3.8 .2 
Opportuni ty Nunber $\underline{3.8 .3}$

Will Consider

$X \quad$ Will Not Consider Implemented

Description: Iransport to the batch plant more than $32 \mathrm{~km}$ distant is not practical. Not Applicable

Opportunity Number 3.8 .4

$x$

Will Consider Will Not Consider Implemented Description: Will be considered during definitive design and implemented as appropriate in the construction specification/s. Opportuni ty Number 5.A.2

Will Consider Will Not Consider Implemented

Description: Piping systems are to constructed on non-metallic materials. Not Appl icable

Opportunity Number 6.B.1

\begin{tabular}{r}
$\mathrm{x}$ \\
\hline Hill \\
Not Consider \\
Implenented \\
Not Appl icable
\end{tabular}

Description: Will be considered during definitive design and implemented as appropriate in the construction specification/s.

Opportunity Nunber 6.8 .2

$x$

Will Consider Will Not Consider Implemented Not Applicable

Description: Will be considered during definitive design and implemented as appropriate in the construction specification/s. Opportunity Number 6.D.1 \begin{tabular}{r} 
Hill Consider \\
\hline$x$ \\
\hline Will Hot Consider \\
Implenented
\end{tabular}

Description: Anticipated quantity of waste wood is de-minimus and not practical to consider by itself. Not Applicable

Opportunity Number $\underline{9.4 .5}$ \begin{tabular}{c}
$\mathrm{x}$ \\
\hline Will \\
Not Consider \\
Implensider
\end{tabular} \begin{tabular}{r}
$\mathrm{x}$ \\
\hline Will \\
$\begin{array}{c}\text { Not Consider } \\
\text { Implemented }\end{array}$
\end{tabular}

Description: Will be considered during definitive design. Hot Appl icable

Opportunity Number $9 . \mathrm{A.6}$

Will Consider $\mathrm{x}$ Will Will Consider
Not Consider
Implemented

Description: De-Minimus painting is required on this project.

Opportunity Number 9.A.7

$\mathrm{x}$

Will Consider Will Not Consider Implemented

Description: Will be considered during definitive desian and imolemented applicable Opportunity Number 9.8 .1

Will Consider 9.8.1 $\mathrm{X}$ Will Not Consider Implenented

Description: De-Minimus painting is required on this project. Not App i icable

Opportunity Nunber 9.8.2

Hill Consider $x \quad$ Will Not Consider Implemented

Description: De-Minimus painting is required on this project. Not Appl icable 
Opportunity Number 9.8 .3

Will Consider ill Not Consider Implemented

Description: De-Minimus painting is required on this project. Not Appl icable

Opportunity Number 9.0.1

Hill Consider $x$ Will Not Consider Impl emented Not Appl icable Description: Will be considered during definitive design and implemented as appropriate in the construction specification/s.

Opportunity Number 11.A.1

Will Consider Will Not Consider Implemented Not Appl icable Description: will be considered during definitive design and implemented as appropriate in the construction specification/s. Opportunity Number 11.A.10

X

Will Consider Will Not Consider 1 mpl emented Not Appl icable Description: will be considered during definitive design and implemented as appropriate in the construction specification/s. Opportunity Number $\underline{11.8 .2}$

Hill Consider Will Not Consider Impl emented Not Applicable Description: Will be considered during definitive design and implemented as appropriate in the construction specification/s. Opportunity Number 15.A.25

$x$

Will Consider Will Not Consider Implemented Not Appl icable Description: Will be considered during definitive design and implemented as appropriate in the construction specification/s. 


\section{$\triangle P P E N D I X$ :}

\section{Sketches}

ES WW504 : CO.1 ES.W504.COL2 ES-W504.0.83 ESWWOH OO ES.W1504 005 ES W504 CO 6 ESW W504-COT
Integrated Site Plan Silte Plati RW line

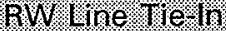
RW. \&. PW LIne TIE-Ih PW Une PW. Une 


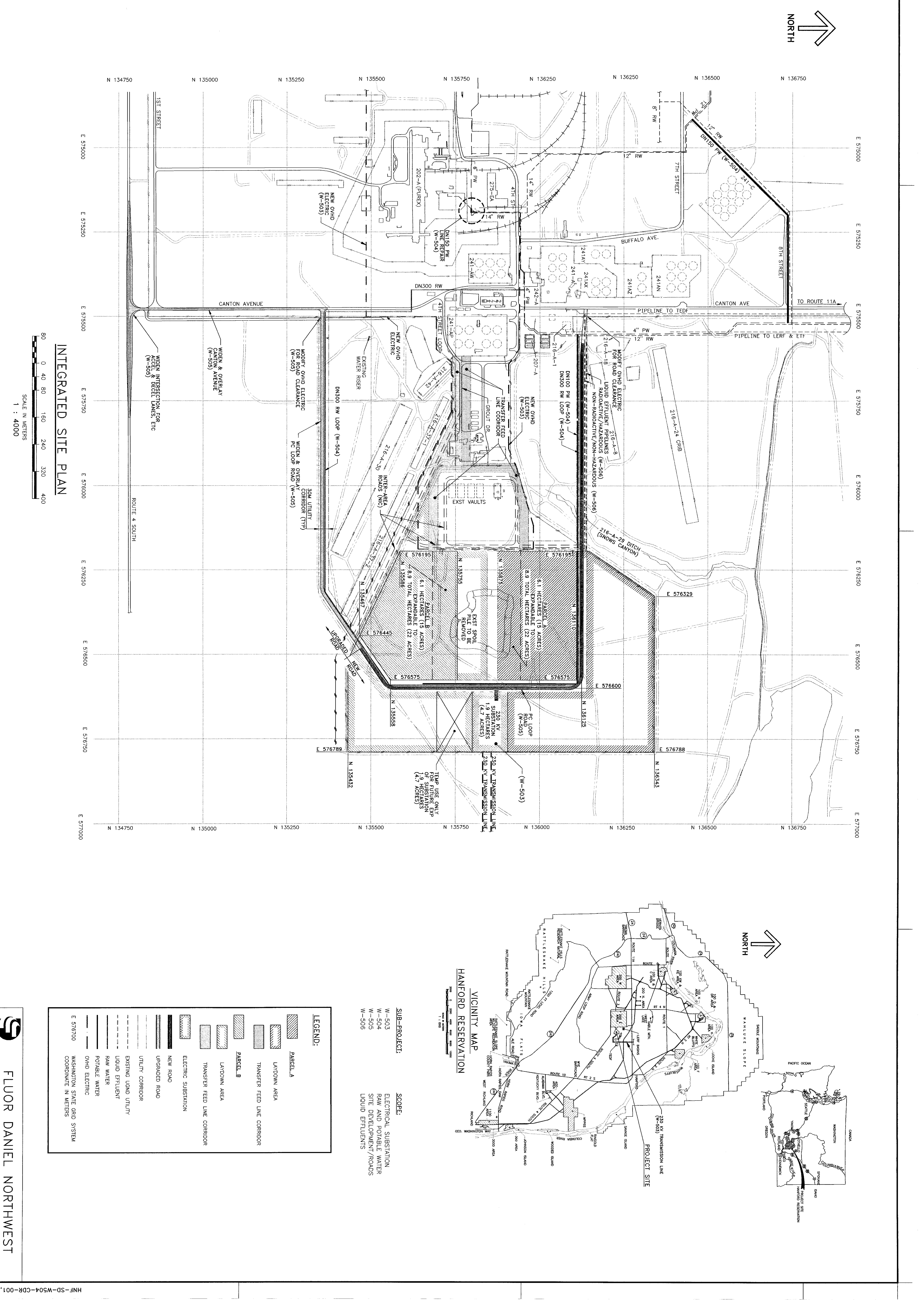



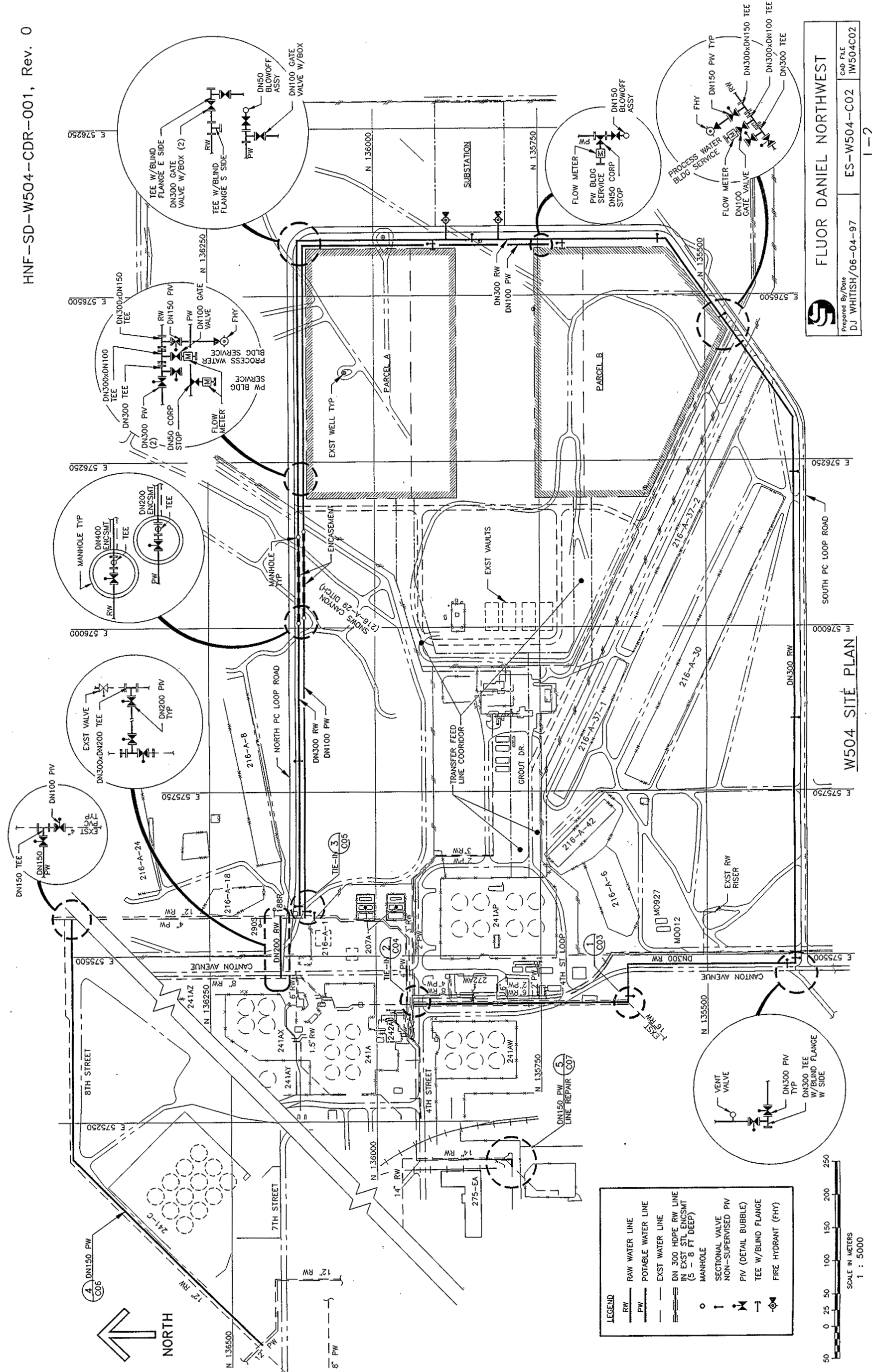


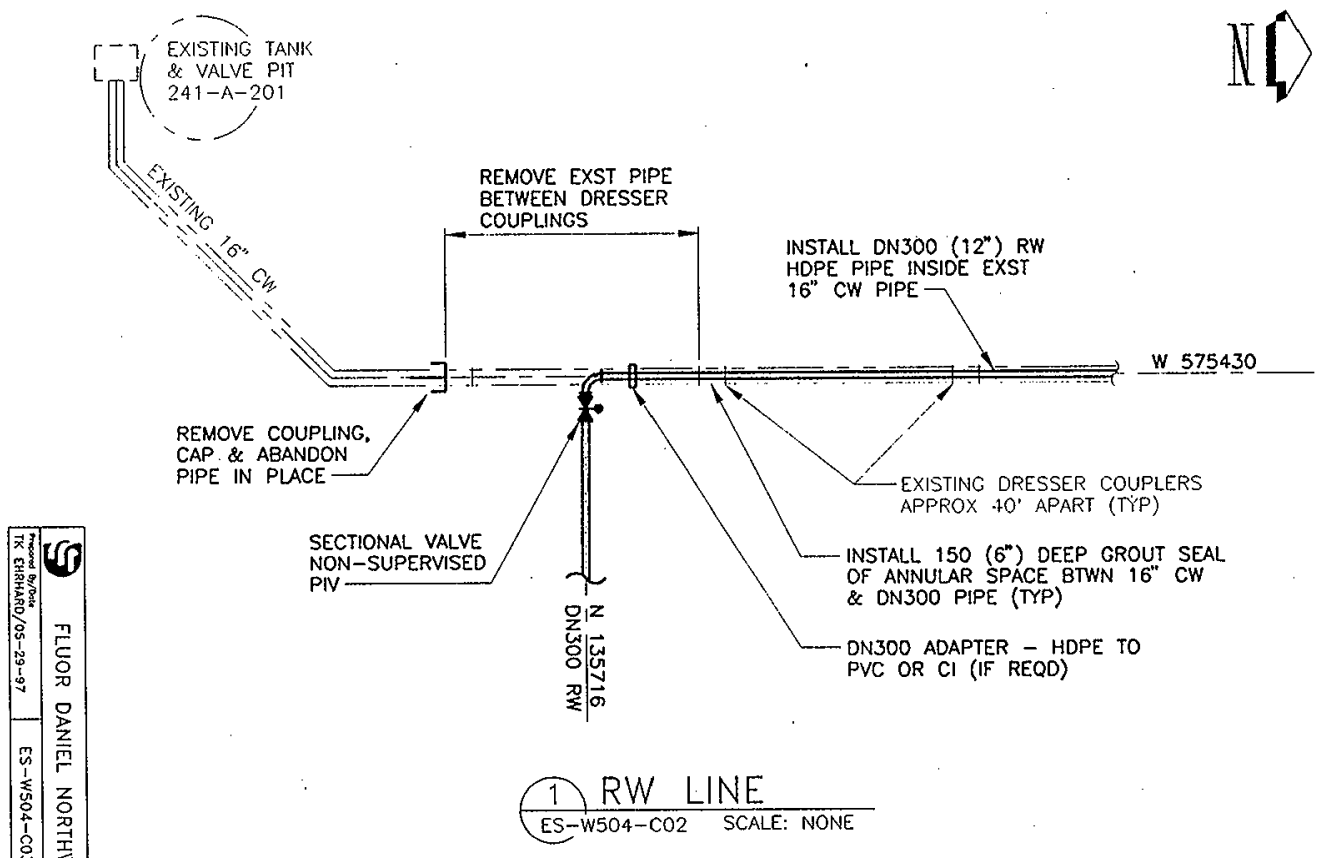


HNF-SD-W504-CDR-001, Rev. 0

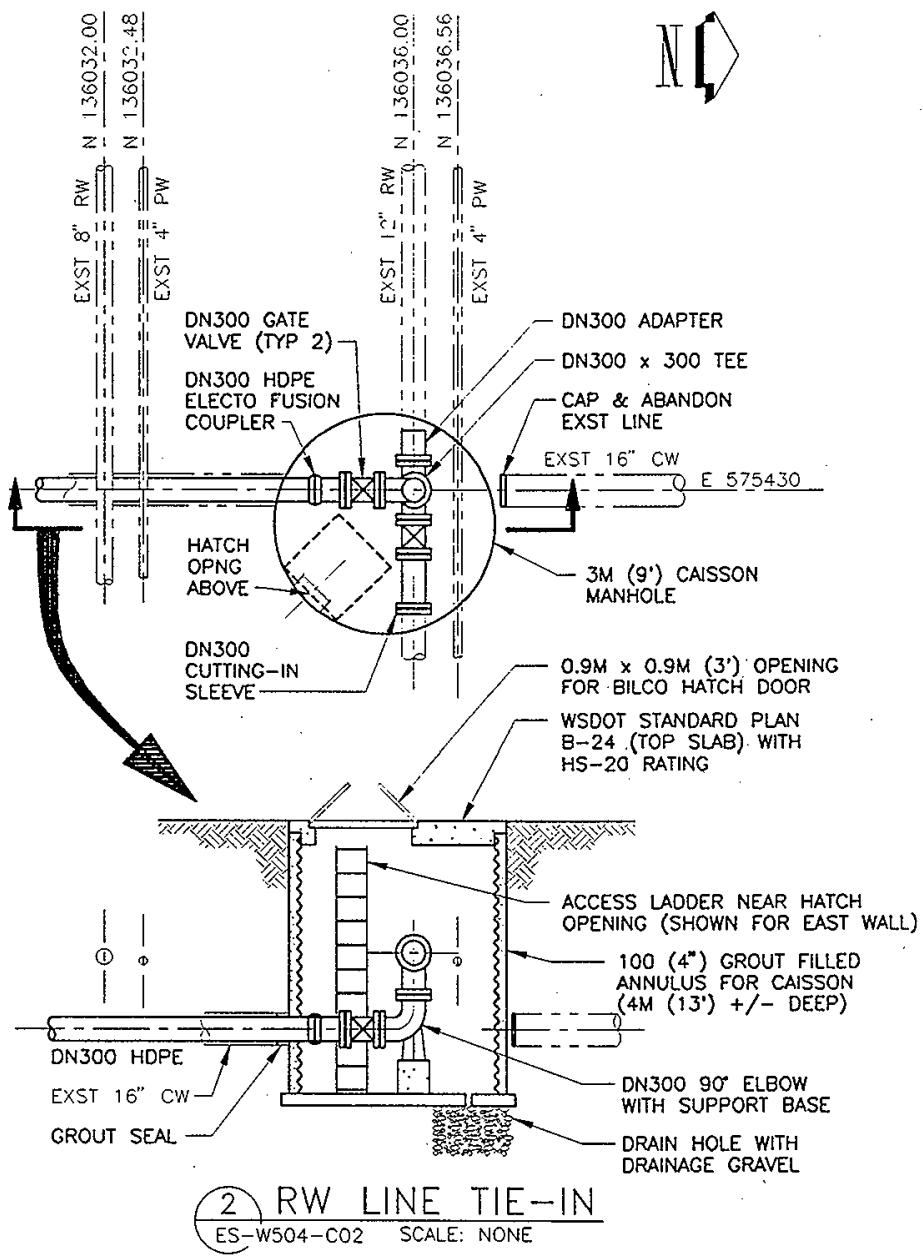

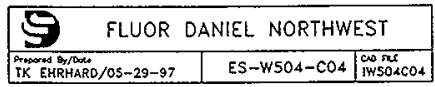




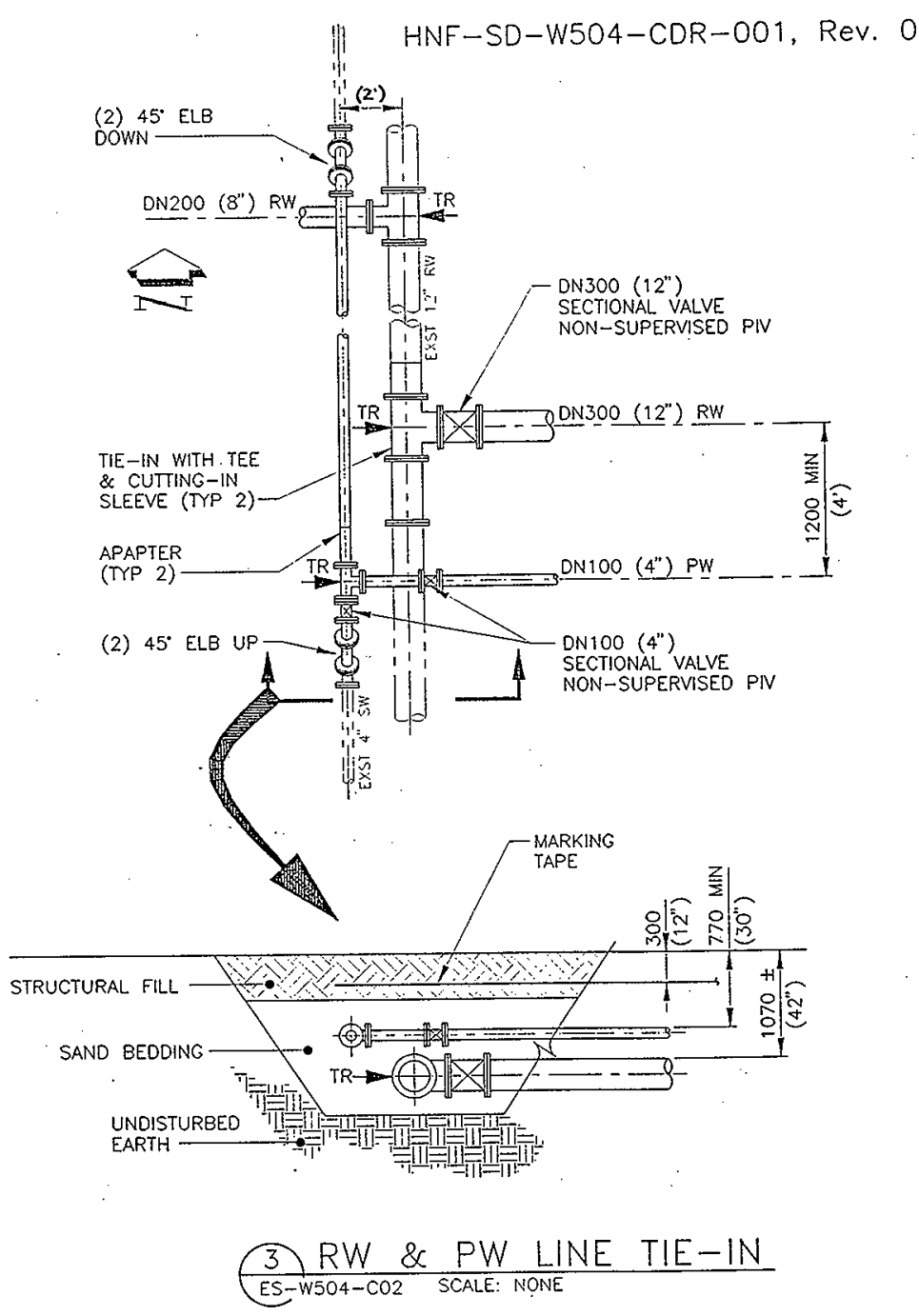

\begin{tabular}{|c|c|}
\hline FLUỌR & DANIEL NORTHWEST \\
\hline 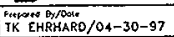 & \begin{tabular}{c|c}
$E S-W 504-C 05$ & $\begin{array}{c}a b r a t \\
1 w 504005\end{array}$ \\
\end{tabular} \\
\hline
\end{tabular}




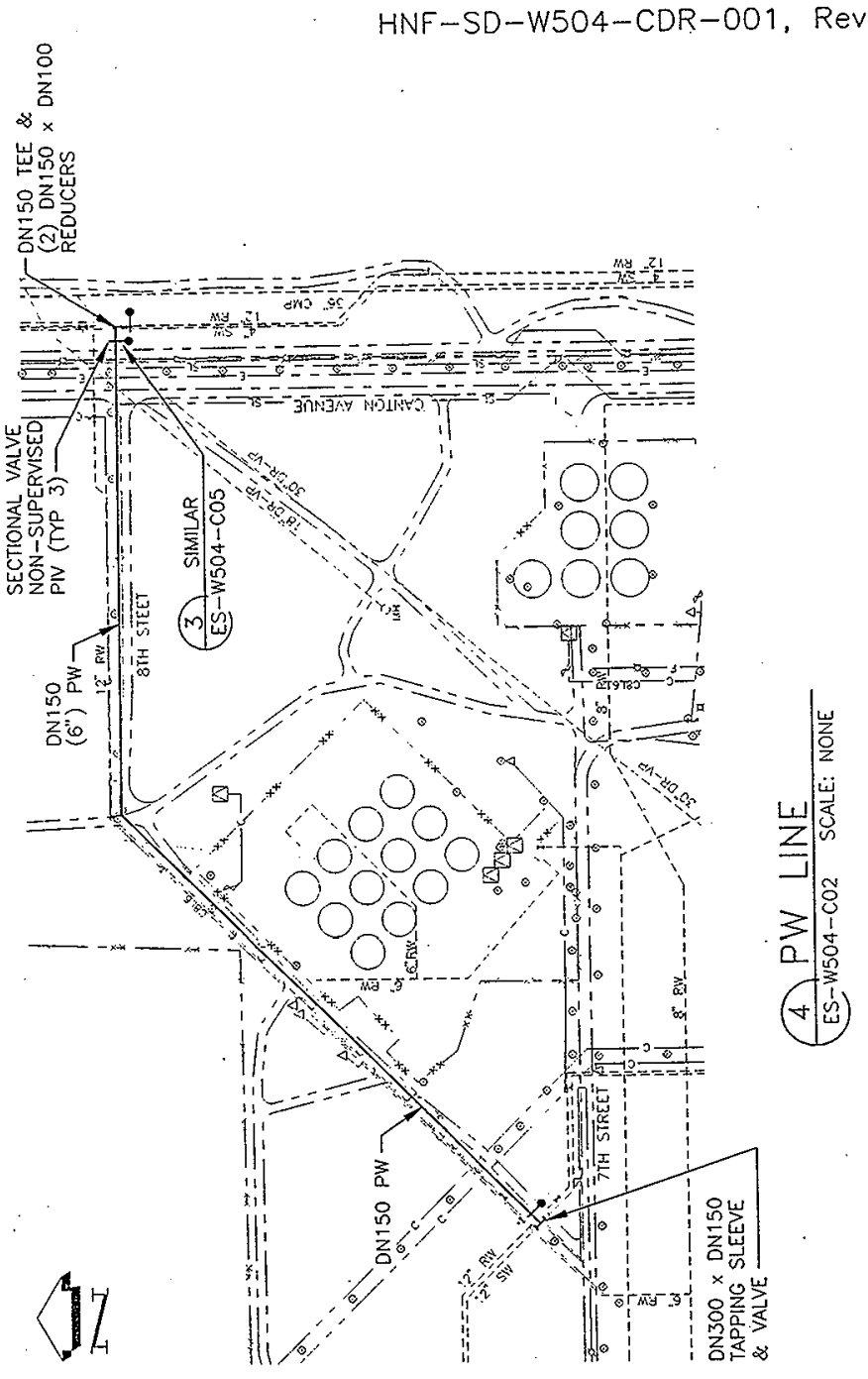

FLUOR DANIEL NORTHWEST

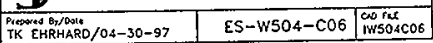



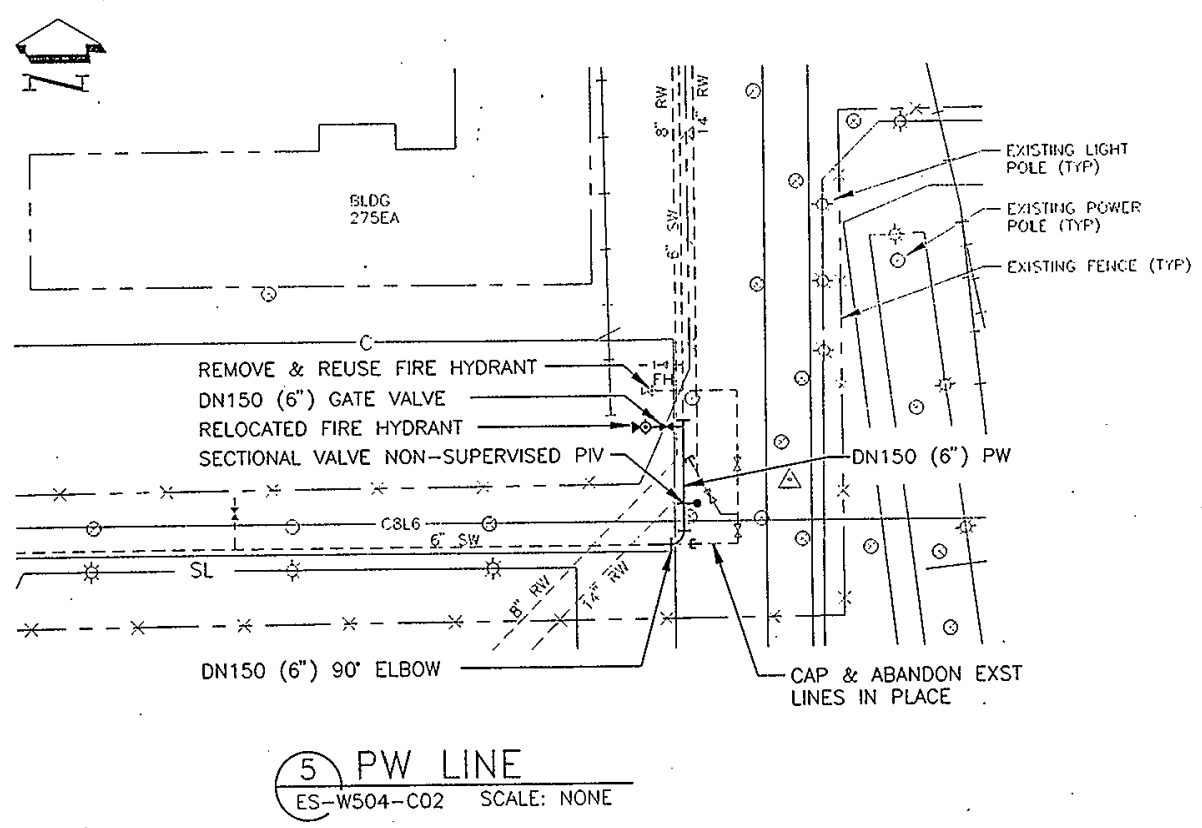


\section{CORRESPONDENCE DISTRIBUTION COVERSHEET}
Author
Addressee
Correspondence No.
Gurdhian Singh
Distribution
EDT 615904

subject: HNF-SD-W504-CDR-001, Rev.0, Conceptual Design Report, "TWRS

Privatization Phase I, Raw and Potable Water, "Subproject W-504

\section{DISTRIBUTION}

Name

Location

w/att

Name

Location

W/att

DOE RICHLAND

* T.R. Hoertkorn

FLUOR DANIEL HANFORD

* A. M. Unek (1)

* S. K. Barnald

(1)

$57-40$

B3-70

$\mathrm{X}$
$\mathrm{X}$

\section{LOCKHEED MARTIN HANFORD CORP.}

\begin{tabular}{|c|c|c|}
\hline $\begin{array}{l}* \text { H. L. Boston } \\
* \text { J. B. Berry } \\
* \text { R. W. Powell } \\
* \text { W. T. Thompson } \\
\text { * M. N. Islam } \\
* \text { P. C. Miller } \\
\text { * W. L. Adams }\end{array}$ & $\begin{array}{l}(1) \\
(1) \\
(1) \\
(1) \\
(1) \\
(1) \\
(1)\end{array}$ & $\begin{array}{l}G 3-21 \\
H 6-37 \\
H 5-03 \\
G 3-21 \\
S 5-12 \\
R 1-51 \\
\text { S5-12 }\end{array}$ \\
\hline
\end{tabular}

\section{MACTEC}

* R. L. Treat (1) H5-03 $\mathrm{X}$

DYNCORP

* J. M. Hache

* D. A. Rohl

(1)

\$2-12

$\$ 2-21$

$X$

\section{NUMATECH HANFORD CORPORATION}

$\begin{array}{cccc}\text { * L. de Lamartinie (1) } & H 5-61 & X \\ \text { * J. N. Alibert (1) } & 52-48 & X \\ \text { * R. J. Parazin } \quad(1) & H 5-49 & X \\ \text { * G. Singh } & \text { (12) } & H 5-49 & X\end{array}$

\section{FLUOR DANIEL NORTHWEST}

\begin{tabular}{|c|c|c|}
\hline $\begin{array}{l}* \text { B. C. Harmon } \\
* \text { D. L. Fort } \\
* \text { K. D. Bare }\end{array}$ & $\begin{array}{l}(3) \\
(1) \\
(1)\end{array}$ & $\begin{array}{l}G 3-08 \\
G 3-12 \\
G 3-08\end{array}$ \\
\hline ESPONDANCE & CONTROL (1) & $\begin{array}{l}11-03 \\
93-11\end{array}$ \\
\hline
\end{tabular}

